
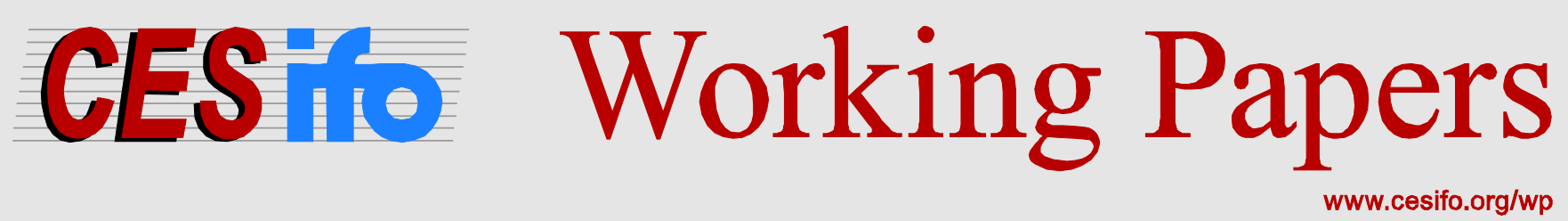

\title{
Optimal Forest Management when Logging Damages and Costs Differ between Logging Practices
}

\author{
Yonky Indrajaya \\ Edwin van der Werf \\ Ekko van Ierland \\ Frits Mohren
}

\begin{abstract}
CESIFO WORKING PAPER NO. 4606
CATEGORY 9: RESOURCE AND ENVIRONMENT ECONOMICS

JANUARY 2014

An electronic version of the paper may be downloaded

- from the SSRN website:

- from the RePEc website:

- from the CESifo website:

WwW.SSRN.com

Www.RePEc.org

www.CESifo-group.org/wp
\end{abstract}




\title{
Optimal Forest Management when Logging Damages and Costs Differ between Logging Practices
}

\begin{abstract}
Papers on optimal harvesting regimes for maximizing land expectation value (LEV) that compare different logging practices often ignore differences in variable costs and in damages on the residual stand between logging practices. We use data on a multi-age, multi-species forest in East-Kalimantan to study optimal harvest regimes for Conventional Logging (CL) and for Reduced Impact Logging (RIL). We simulate a range of carbon prices with compensation for additional carbon stored under sustainable forest management (RIL). According to our detailed data, RIL has higher fixed costs but lower variable costs than CL, and leads to less damages on the residual stand. We show that when these differences are taken into account, RIL leads to highest LEV for low to intermediate carbon prices, while for high carbon prices conventional logging is preferred. Conventional logging, however, does not qualify for carbon payments. Furthermore, we show that ignoring damages in the model leads to vast overestimations of LEV and large underestimations of optimal cutting cycles for all carbon prices, and to a different choice of logging practice for low and high carbon prices. Ignoring differences in variable costs between CL and RIL leads to small overestimations of LEV for low carbon prices and small underestimations of LEV for high carbon prices, with small to zero differences in optimal cutting cycles.
\end{abstract}

JEL-Code: Q230, Q570.

Keywords: sustainable forest management, reduced impact logging, optimal forest management, REDD, carbon price.

Yonky Indrajaya*

Environmental Economics \& Natural

Resources Group/Wageningen University

The Netherlands - 6706 KN Wageningen

yonky.indrajaya@wur.nl

Ekko van Ierland

Environmental Economics \& Natural

Resources Group/Wageningen University

The Netherlands - 6706 KN Wageningen

ekko.vanierland@wur.nl
Edwin van der Werf

Environmental Economics \& Natural Resources

Group/Wageningen University

The Netherlands - $6706 \mathrm{KN}$ Wageningen

edwin.vanderwerf@wur.nl

Frits Mohren

Forest Ecology \& Forest Management Group, Wageningen University

The Netherlands - 6706 KN Wageningen

frits.mohren@wur.nl

*corresponding author

We would like to thank Landry Fanou, Petrus Gunarso, Haruni Krisnawati, Hari Priyadi, Plinio Sist, Sudarsono Sudomo, Hans-Peter Weikard and Pieter Zuidema for useful comments and discussions. This research was financed by the Tropenbos International Indonesia Programme and the Forestry Research and Development Agency Indonesia. 


\section{INTRODUCTION}

Sustainable forest management (SFM) ensures the continuous flow of wood products and employment while maintaining or even improving the functionalities of the forest in providing environmental services, such as carbon sequestration and biodiversity, as compared to conventional management and exploitation (Sasaki et al., 2012). In tropical forests, SFM procedures rely on government regulations on cutting cycles, minimum felling-diameter, and maximum per unit-area harvest intensities. These procedures are usually applied in combination with proven techniques for reducing damage to the residual stand, i.e. reduced impact logging (RIL; Zimmerman and Kormos, 2012). Through intensively planned and carefully controlled timber harvesting, conducted by trained workers, RIL practices decrease the deleterious impacts of logging (Putz et al., 2008b) and, ceteris paribus, retain a larger carbon stock in the remaining forest stand as compared to conventional logging (CL) practices (Pinard and Putz, 1996; Putz and Pinard, 1993). While RIL leads to less damage to the residual stand, it may lead to higher harvesting costs (Boltz et al., 2001; Boscolo and Buongiorno, 1997; Boscolo et al., 1997; Holmes et al., 2000; Medjibe and Putz, 2012; Putz et al., 2008a).

Papers on optimal harvesting regimes in tropical forests that study different logging practices often ignore differences in (variable) harvesting costs (e.g. Boscolo and Buongiorno, 1997; Boscolo et al., 1997) and differences in damages to the residual stand (e.g. Ingram and Buongiorno, 1996), or rely on ad-hoc assumptions on damages (e.g. Boscolo and Buongiorno, 1997; Boscolo et al., 1997; Boscolo and Vincent, 2000).

In this paper, we analyze the effects of the differences in residual stand damage and harvesting costs for conventional logging and reduced impact logging on the respective optimal cutting cycles and land expectation values. We use detailed data on these characteristics for a multiage, multi-species forest in East-Kalimantan, Indonesia, and simulate a Faustmann model for a range of carbon prices and different harvest diameter limits. While several authors have found that residual stand damage differs over diameter classes (Macpherson et al., 2010; Priyadi et al., 2007) and depends on harvest intensity and logging technique (Bertault and Sist, 1997; Macpherson et al., 2010; Priyadi et al., 2007; Sist et al., 1998; Sist et al., 2003b), the literature on optimal harvesting regimes for the tropics largely ignores these facts. Boscolo and Buongiorno (1997) and Boscolo and Vincent (2000) assume that the damage on residual stand depends on the size and the number of the trees harvested, but only affects the smallest diameter class. Ingram and Buongiorno (1996) ignore the damage on residual stand. Following Macpherson et al. (2010), we allow damage to depend on harvest intensity and logging technique, and to differ over diameter classes. We show that when differences in costs and damages are taken into account, the highest land expectation value (LEV) for low to intermediate carbon prices is obtained using RIL, while for high carbon prices conventional logging is preferred. Furthermore, we show that ignoring damages in the model leads

to vast overestimations of LEV and large underestimations of optimal cutting cycles for all carbon prices, and to different choices of logging practices for low and high carbon prices. Boscolo et al. 
(1997) and Boscolo and Vincent (2000) assume differences in fixed costs but not in variable costs for CL and RIL. According to our detailed data, on East-Kalimantan, RIL has higher fixed costs but lower variable costs than CL. Ignoring differences in variable costs between CL and RIL leads to small overestimations of LEV for low carbon prices and small underestimations of LEV for high carbon prices, with small to zero differences in optimal cutting cycles.

The current paper is also rooted in the literature on forest economics and carbon pricing (Boscolo et al., 1997; Buongiorno et al., 2012; Galinato and Uchida, 2011; Olschewski and Benitez, 2010; Tassone et al., 2004, van Kooten et al., 1995). Most papers study the effect of incentives for carbon sequestration on the amount of carbon stored, starting from bare land. We model the incentives from the market for voluntary carbon credits, awarded for reducing emissions from deforestation and forest degradation (REDD+), through switching from conventional logging to reduced impact logging. Our results show that switching to reduced impact logging can significantly increase carbon storage already at low carbon prices. In addition, we find that there exists a range of carbon prices for which $\mathrm{CL}$ is the low-cost carbon sequestration technique, even though under REDD+ it does not qualify for carbon payments as it is not a sustainable management practice.

The remainder of this paper is organized as follows. We first describe the forest transition growth model and economic optimization model. Next we parameterize the model in section 3 . We present our results in section 4 and conclude in section 5 .

\section{MODEL}

\subsection{Forest Growth Model}

Matrix stand growth models are an extension of population growth models applied to forest stands (Buongiorno and Michie, 1980). Such models have been applied to tropical forest stands to study management strategies for maximized economic returns (Boscolo and Buongiorno, 1997; Boscolo and Vincent, 2000; Ingram and Buongiorno, 1996).

At time $t$ the stand state of a forest is represented by column vector $\mathbf{y}_{t}=\left[y_{i j t}\right]$, where $y_{i j t}$ is the number of trees per ha of species group $i, k \in\{1, \ldots, m\}$ and diameter class $j \in\{1, \ldots, n\}$. The harvest is represented by vector $\mathbf{h}_{t}=\left[h_{i j t}\right]$. A tree that lives in species group $i$ and diameter class $j$ at time $t$ will at time $t+\theta$, either: (1) die, which happens with probability $o_{i j}$, (2) stay alive and move up from class $j$ to class $j+1$, which happens with probability $b_{i j}$, or (3) stay alive in the same diameter class $j$, which happens with probability $a_{i j}=1-b_{i j}-o_{i j}$. Parameter $\theta$ represents the growth interval, i.e. the length of growth period (years).

Let us denote $I_{i t}$ as the expected ingrowth or the number of trees entering the smallest size class of species groups $i$ during interval $\theta$. The stand state at time $t+\theta$ is determined by the conditions of the entire stand at time $t$, the harvesting at time $t$, and the ingrowth during interval $\theta$. Ignoring damages from harvesting at the moment, the stand state is represented by the following $n$ equations: 


$$
\begin{gathered}
y_{i, 1, t+\theta}=I_{i, t}+a_{i, 1}\left(y_{i, 1, t}-h_{i, 1, t}\right) \\
y_{i, 2, t+\theta}=b_{i, 1}\left(y_{i, 1, t}-h_{i, 1, t}\right)+a_{i, 2}\left(y_{i, 2, t}-h_{i, 2, t}\right) \\
\ldots \\
y_{i, n, t+\theta}=b_{i, n-1}\left(y_{i, n-1, t}-h_{i, n-1, t}\right)+a_{i, n}\left(y_{i, n, t}-h_{i, n, t}\right)
\end{gathered}
$$

Ingrowth $I_{i t}$ is affected by the conditions of the stand (i.e. basal area and number of trees). The ingrowth function is a function of basal area $B_{i j}$, the initial stand and the harvest:

$$
I_{i t}=\beta_{0 i}-\beta_{1 i} \sum_{j=1}^{n} B_{i j}\left(y_{i j t}-h_{i j t}\right)+\beta_{2 i} \sum_{j=1}^{n}\left(y_{i j t}-h_{i j t}\right)
$$

$\beta_{0 i}, \beta_{1 i}, \beta_{2 i}>0$. Substituting Eq. (2) into the first equation of (1) gives:

$$
y_{i, 1, t+\theta}=\beta_{0 i}+e_{i 1}\left(y_{i, 1, t}-h_{i, 1, t}\right)+\cdots+e_{i n}\left(y_{i, n, t}-h_{i, n, t}\right)
$$

where:

$$
\begin{gathered}
e_{i 1}=a_{i 1}+\beta_{1 i} B_{i 1}+\beta_{2 i} \\
e_{i j}=\beta_{1 i} B_{i j}+\beta_{2 i} \text { for } j>1
\end{gathered}
$$

Ignoring damage for the time being, the stand state after harvest is:

$$
\mathbf{y}_{t+\theta}=\mathbf{G}\left(\mathbf{y}_{t}-\mathbf{h}_{t}\right)+\mathbf{c}
$$

where

$$
\mathbf{G}=\mathbf{A}+\mathbf{R}
$$

and

$$
\begin{gathered}
\mathbf{A}=\left[\begin{array}{cccc}
\mathbf{A}_{1} & 0 & \ldots & 0 \\
0 & \mathbf{A}_{2} & \ldots & 0 \\
\vdots & \vdots & \ddots & \vdots \\
0 & 0 & \ldots & \mathbf{A}_{m}
\end{array}\right] ; \mathbf{A}_{i}=\left[\begin{array}{cccc}
a_{i 1} & & & 0 \\
b_{i 2} & a_{i 2} & & \\
& \ddots & \ddots & \\
0 & & b_{i n} & a_{i n}
\end{array}\right] \\
\mathbf{R}=\left[\begin{array}{cccc}
\mathbf{R}_{11} & \mathbf{R}_{12} & \ldots & \mathbf{R}_{1 m} \\
\mathbf{R}_{21} & \mathbf{R}_{22} & \ldots & \mathbf{R}_{2 m} \\
\vdots & \vdots & \ddots & \vdots \\
\mathbf{R}_{m 1} & \mathbf{R}_{m 2} & \ldots & \mathbf{R}_{m m}
\end{array}\right] ; \mathbf{R}_{i k}=\left[\begin{array}{cccc}
e_{i 1} & e_{i 2} & \ldots & e_{i n} \\
0 & 0 & \ldots & 0 \\
\vdots & \vdots & \ddots & \vdots \\
0 & 0 & \ldots & 0
\end{array}\right]
\end{gathered}
$$




$$
\mathbf{c}=\left[\begin{array}{c}
\mathbf{c}_{1} \\
\mathbf{c}_{2} \\
\vdots \\
\mathbf{c}_{m}
\end{array}\right] ; \quad \mathbf{c}_{i}=\left[\begin{array}{c}
\beta_{i 0} \\
0 \\
\vdots \\
0
\end{array}\right]
$$

Matrix $\mathbf{G}$ is the growth matrix. $\mathbf{A}$ is an $m n \times m n$ matrix consisting of upgrowth matrices $\mathbf{A}_{i}$ for species $i$. It represents the probability of a tree to stay alive in the same diameter class $j$, or move up the next diameter class $j+1$. Ingrowth matrix $\mathbf{R}$ is an $m n \times m n$ matrix representing the effect of stand structure on the probability of a tree entering the smallest diameter class in one growth period. Vector c contains the ingrowth constants representing the number of trees exogenously entering the smallest diameter class for each species.

\subsection{Economic Model}

\subsubsection{Maximizing Timber Revenues}

The unit of analysis in this study is one hectare of a forest stand. Following the model, the economic harvesting decision involves three features: (1) the length of the cutting cycle, (2) the intensity of the harvest (Buongiorno et al., 1994; Chang, 1981), and (3) the type of harvesting practice (Boltz et al., 2003; Dwiprabowo et al., 2002). For a given cutting cycle $T$, which is a product of the growth period $\theta$ and parameter $\gamma$ (which we explain below), we can formulate the problem of maximizing the land expectation value (LEV) over an infinite horizon subject to damage, harvest and steady state equilibrium constraints:

$$
\max _{\mathbf{y}_{T}, \mathbf{h}_{T}} L E V=\frac{\mathbf{v}_{S}^{\prime} \mathbf{h}_{T}-F_{S}}{(1+r)^{T}-1}-\mathbf{v}_{S}^{\prime} \mathbf{z}_{T}
$$

subject to

$$
\begin{gathered}
\mathbf{z}_{T}=\left(\mathbf{y}_{T}-\mathbf{h}_{T}-\mathbf{d}_{s T}\right) \\
\mathbf{d}_{s T}=f_{s}\left(h_{i j T}, y_{i j T}\right) \\
\mathbf{y}_{t+\theta}=\mathbf{G} \mathbf{z}_{t}+\mathbf{c} \\
\mathbf{y}_{t+2 \theta}=\mathbf{G}\left(\mathbf{y}_{t+\theta}\right)+\mathbf{c} \\
\ldots \\
\mathbf{y}_{t+\gamma \theta}=\mathbf{G}\left(\mathbf{y}_{t+\theta(\gamma-1)}\right)+\mathbf{c} \\
\mathbf{y}_{T} \geq \mathbf{h}_{T}+\mathbf{d}_{s T} \\
\mathbf{h}_{T}, \mathbf{y}_{T}, \mathbf{z}_{T} \geq 0
\end{gathered}
$$




$$
\begin{gathered}
h_{i j}=0 \text { for all } j<\eta \\
\mathbf{y}_{t}=\mathbf{y}_{t+\gamma \theta} \text { for all } t=1, \ldots, \infty
\end{gathered}
$$

Vector $\mathbf{v}_{S}$ represents the value of the trees (i.e. price minus variable costs and taxes) under logging practice $s$, where $v_{i j}$ is the value of a tree of species $i$ in diameter class $j$. We denote $s$ as the logging practice, where $s=\mathrm{CL}$ represents conventional logging and $s=$ RIL represents reduced impact logging. $F_{S}$ represents the fixed costs per ha of harvesting using harvesting practice $s$; $r$ represents the real discount rate; $\mathbf{z}_{t}$ represents residual stand after harvest, where $z_{i j}$ is the number of trees that remain in species $i$ of diameter class $j$ after harvest; and $\gamma$ is the number of growth periods $\theta$ within the harvesting cycle $(T)$. Equation (13) represents the damage on the residual stand caused by harvesting activities. The damage to the residual stand is a function of overall harvest intensity and is represented by the $m n \times 1$ vector, $\mathbf{d}_{s T}$. Equations (14)-(16) represent the growth of the forest state. Equations (17) and (18) are the harvest and non-negativity constraints. Equation (19) represents the minimum diameter harvested, where $\eta$ is the minimum diameter harvested restricted by government regulation. Equations (20) shows the equilibrium steady state constraint. We solve Equation (11)-(20) for different values of $\gamma$ and then find the value of $\gamma$ that maximizes the land expectation value.

\subsubsection{Maximizing Timber and Carbon Revenues}

As carbon storage in live biomass is decreased when harvesting, this disturbance counteracts carbon storage through tree growth and biomass accumulation. Additional revenues from payments for retaining carbon stored in forest biomass and end-use products can change optimal harvesting intensity, cutting cycle, and harvesting technique and thereby mitigate carbon losses. The baseline against which additionality of carbon storage is measured is the average amount of greenhouse gases (in tons of $\mathrm{CO}_{2}$ eq.) that is stored in above ground biomass $(A G B)$ and end-use wood products under CL calculated over one management cycle, $\bar{C}_{C L}$. Verification takes place every $\theta$ years while payment for avoiding carbon emissions takes place at the end of the cutting cycle. In addition, we assume the carbon project can be renewed. Hence, following Hartman (1976), the objective function in presence of carbon payments may be written as follows:

$$
\max _{\mathbf{y}_{T,} \mathbf{h}_{T}} L E V=\frac{\mathbf{v}_{R I L}^{\prime} \mathbf{h}_{T}-F_{R I L}+p \sum_{t=0}^{T-\theta}\left(C_{R I L, t}-\bar{C}_{C L}\right)(1+r)^{T-t}}{(1+r)^{T}-1}-\mathbf{v}_{R I L}^{\prime} \mathbf{z}_{T}+\left(C_{R I L, 0}-\bar{C}_{C L}\right)
$$

with

$$
\begin{gathered}
C_{R I L, t}=\chi^{\prime} \mathbf{y}_{R I L, t}+\chi^{\prime} \mathbf{h}_{R I L, T}\left(1-u_{R I L}\right) \omega(1+\delta)^{-t} \\
C_{C L, t}=\chi^{\prime} \mathbf{y}_{C L, t}+\chi^{\prime} \mathbf{h}_{C L, T}\left(1-u_{C L}\right) \omega(1+\delta)^{-t}
\end{gathered}
$$




$$
\bar{C}_{C L}=\frac{1}{\gamma} \sum_{t=0}^{T-\theta} C_{C L, t}
$$

where $p$ is the price per ton of $\mathrm{CO}_{2}$ eq. stored. The carbon credit price $p$ is the price of a temporary carbon credit for a project that can be renewed after it expired. ${ }^{1} C_{R I L}$ represents the total amount of carbon stored in tree biomass in above ground biomass and in end used wood product under RIL. Sasaki et al. (2012) pointed out that not all harvested wood will be used in end-use products, but a proportion $u_{s}$ will be wasted due to logging, skidding, and transportation activities. From the remaining timber arriving at the sawmill, only a proportion $\omega$ is used in end-use wood products. We assume that the carbon stored in logging waste $u_{s}$ and end-use wood waste $(1-\omega)$ is released immediately after harvesting and wood processing, whereas end-use wood products will be oxidized with an annual oxidation rate $\delta$. Vector $\chi$ represents the amount of greenhouse gases (in tons of $\mathrm{CO}_{2}$-eq.) stored in above-ground forest biomass and wood product per tree of species $i$ and diameter class $j$, with the following relation: $\boldsymbol{\chi}=\mathbf{A G B} \times \tau \times 44 / 12$. Vector AGB is the vector of above-ground biomass, $\tau$ is the proportion of amount of carbon stored in tree biomass, and 44/12 is the ratio of molecular mass of $\mathrm{CO}_{2}$ to the atomic mass of carbon. To estimate the amount of aboveground biomass (AGB) for diameter class $j$ of each species, we take the middle point of the respective diameter class and use the following allometric equation (Chave et al., 2005):

$$
A G B_{j}=\rho \exp \left(\alpha_{0}+\alpha_{1} \ln D B H+\alpha_{2} \ln D B{H_{j}}^{2}+\alpha_{3} \ln D B H_{j}{ }^{3}\right)
$$

where $\alpha_{0}, \alpha_{1}, \alpha_{2}$, and $\alpha_{3}$ are coefficients, $D B H$ represents the diameter of a tree at breast height, and $\rho$ represents the wood density.

\section{PARAMETERIZATION OF THE MODEL}

\subsection{Forest Growth Data}

We use the growth matrix developed by Krisnawati et al. (2008) for lowland dipterocarp forest in Kalimantan. The data from Krisnawati et al. (2008) were collected $190-225$ m above sea level. The soil type is dominated by podzolic soils. The climate is classified as type A (Schmidt and Ferguson classification) with an annual precipitation rate of 3,520 mm (Samsoedin et al., 2009). The highest and lowest monthly temperatures are $27.4^{\circ} \mathrm{C}$ and $24.3^{\circ} \mathrm{C}$ respectively. The forest is dominated by dipterocarp species including Shorea $s p$ and Dipterocarpus $s p$. We use a growth period $\theta$ of 2 years because observations by Krisnawati et al. (2008) were conducted in 1 and 2 years, and the authors found that the observation period of 2 years could produce more accurate data for the increment of tree diameter and volume. There are three species groups $i$ in the growth matrix with $i=1$ for commercial dipterocarp, $i=2$ for commercial non-dipterocarp, and $i=3$ for non-commercial species. Each species group $i$ consists of 135 -centimeter diameter classes $(j=$ 1 for $10-14 \mathrm{~cm} \mathrm{DBH}$, and $j=13$ for $>70 \mathrm{~cm} \mathrm{DBH})$. The complete growth matrices are presented

\footnotetext{
${ }^{1}$ The relation between the price of carbon credits from temporary carbon projects, $p$, and the price of permanent projects, such as the price in the EU ETS, $p_{\infty}$, can be expressed as follows: $p=p_{\infty}\left(1-(1+r)^{-\theta}\right)$.
} 
in Appendix 1. Short term validation of the growth model was done by Krisnawati et al. (2008), who concluded that the predicted number of trees in each species and diameter class are not significantly different from the observed values. Following Bollandsas et al. (2008), we conduct the long term validation by simulating the matrix growth model without harvesting for 1000 years starting from bare land. Figure 1 shows the basal areas of the forest in the steady state. The simulation results show that the climax forest is reached around year 300. In the climax steady state, basal area of the stand is $26.4 \mathrm{~m}^{2} /$ ha with a volume of $330 \mathrm{~m}^{3} /$ ha and carbon stored in above ground and below ground biomass is 251 ton/ha. This predicted climax forest is slightly thinner than the virgin forest measured in Kalimantan by Sist et al., (2003b), which has a basal area of $\pm 30 \mathrm{~m}^{2} / \mathrm{ha}$, and is similar to the basal area of $25 \mathrm{~m}^{2} /$ ha and the 214 ton/ha of carbon stored in biomass of in the climax forest resulting from the growth matrix used in Boscolo and Buongiorno (1997) and Boscolo and Vincent (2000).

The dipterocarp species dominates the stand of the climax forest with a basal area of 19.4 $\mathrm{m}^{2} /$ ha $(74 \%)$, whereas the basal area of the commercial non-dipterocarp and non-commercial species are $5.8 \mathrm{~m}^{2} / \mathrm{ha}(22 \%)$ and $1.1 \mathrm{~m}^{2} / \mathrm{ha}(4 \%)$ respectively. The growth matrix of Krisnawati et al. (2008) was developed in a logged-over forest with high felling intensity. Since the growth rate of dipterocarp is faster than non-dipterocarp species (Priyadi et al., 2007; Vanclay, 1994), the number of trees from dipterocarp species will dominate the stand composition of the climax forest.

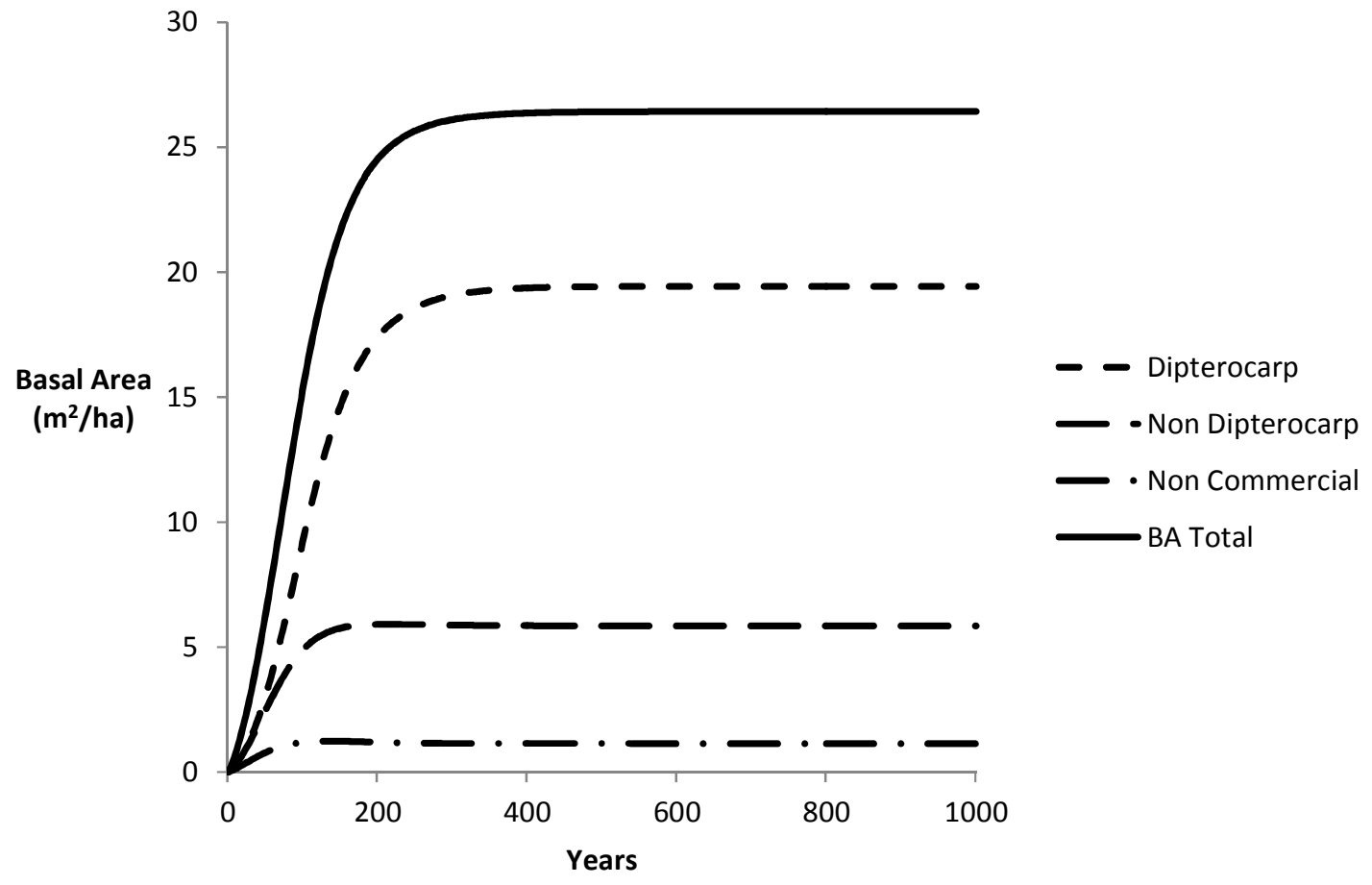

Figure 1. Predicted basal area (BA) of commercial dipterocarp, commercial non-dipterocarp and non-commercial species without harvest. 


\subsection{Harvest Damage Relation}

Following the approach by Macpherson et al. (2010), the number of trees damaged because of harvesting activities is $\mathbf{d}_{s T}=\left(\sum_{i} \sum_{j} h_{i j t}\right) \mathbf{D}_{s} \mathbf{y}_{t}$, where $\mathbf{D}_{s}$, a damage matrix, is an $m n \times m n$ matrix where the diagonal contains the logging damage coefficients under logging practice $s$. The damage coefficients represent the proportion of trees killed per tree harvested within each species group $i$ and size $j$. Matrix $\mathbf{D}_{s}$ consists of damage coefficient matrices $\mathbf{E}_{s}$ and null matrices:

$$
\mathbf{D}_{s}=\left[\begin{array}{lll}
\mathbf{E}_{s} & & 0 \\
& \mathbf{E}_{s} & \\
0 & & \mathbf{E}_{s}
\end{array}\right]
$$

According to the CIFOR data (Priyadi et al., 2007) we used to generate $\mathbf{D}_{s}$, RIL reduces damages per tree harvested with $17 \%$ on average over all diameter classes, and with $25 \%$ on average for all trees of $50 \mathrm{~cm} \mathrm{DBH}$ and larger. The matrices $\mathbf{E}_{s}$ are presented in Appendix 1. The data from Priyadi et al. (2007) come from experimental plots in Kalimantan, where different logging practices have been applied. In their study, the minimum-diameter harvested is $50 \mathrm{~cm}$, based on the Indonesian selective logging system (TPTI) that was applied until 2009. In our simulations, the minimum diameter for harvest, $\eta$, is set at $40 \mathrm{~cm}, 50 \mathrm{~cm}$, and 60 for RIL, whereas for CL it is set at $40 \mathrm{~cm}$. In the new Indonesian selective logging system, effective since 2009, the minimum diameter harvested is $40 \mathrm{~cm}$ (Ministry of Forestry, 2009b).

\subsection{Economic Parameters}

We use production cost parameters reported by Dwiprabowo et al. (2002) for CL and RIL for a tropical forest concession on East-Kalimantan. ${ }^{2}$ The investment and administration costs data were collected from a technical proposal of a company in Kalimantan (PT Sumalindo Lestari Jaya, 2008). ${ }^{3}$ The gross prices of timber per $\mathrm{m}^{3}$ are based on standard prices determined by the Indonesian government in which commercial species are sorted into two groups: dipterocarp and non-dipterocarp. ${ }^{4}$ The net price $\mathbf{v}_{s}$ is the gross price of timber minus the variable costs, fees, and taxes per cubic meter. Total variable costs are slightly lower for RIL than for CL (46.4 USD/m $\mathrm{m}^{3} \mathrm{vs}$ $44.8 \mathrm{USD} / \mathrm{m}^{3}$ ), whereas the fixed costs per harvest for RIL are substantially higher than those for CL (390 and 297 USD/ha per harvest respectively). The fixed costs differ as a result of different machines used and additional pre-harvesting activities with RIL such as data checking and

\footnotetext{
${ }^{2}$ We express values in USD of 2012, using an average inflation rate of 7.6\% for 2002-2012 and an exchange rate of 1 USD = 9.387 IDR for 2012 (World Bank World Development Indicators).

${ }^{3}$ We express values in USD of 2012, using an average inflation rate of 4.9\% for 2009-2012 and an exchange rate of 1 USD = 9.387 IDR for 2012 (World Bank World Development Indicators).

${ }^{4}$ Ministry of Trade Decree No 22/M-DAG/PER/4/2012. The dipterocarp species price used is $1.270 .000 \mathrm{IDR} / \mathrm{m}^{3}$ and the price for commercial non-dipterocarp is $953.000 \mathrm{IDR} / \mathrm{m}^{3}$.
} 
mapping, skidtrail marking and checking, software purchasing, vine cutting, and improved timber inventory and contour survey (Dwiprabowo et al., 2002). Our data are similar to data from Boltz et al. (2001) in that the variable costs are higher for CL than that for RIL and the fixed costs are higher for RIL than those for CL. The resulting net price (standard price minus variable costs and taxes) is $60 \mathrm{USD} / \mathrm{m}^{3}$ for dipterocarp and $32 \mathrm{USD} / \mathrm{m}^{3}$ for non-dipterocarp.

Regarding variable costs, additional activities with RIL, such as training and supervision, also imply higher costs. However, this is more than offset by higher skidding costs with CL (Dwiprabowo et al., 2002). The details of the cost parameters and taxes used in this study are presented in Appendix 2. We use a discount rate of $4 \%$ for our main analyses, based on the average real interest rate for Indonesia for the past 10 years. ${ }^{5}$ In section 4.3 .4 we present results for a sensitivity analysis for different values of the discount rate.

\subsection{Wood Volume and Carbon Stored in Tree Biomass}

We estimate wood volume based on the formula developed by Enggelina (2001) for dipterocarp and non-dipterocarp species in Kalimantan. Because there are no data for wood volume estimation for non-commercial species, we assume that the formula for wood volume estimation for non-dipterocarp can also be applied for non-commercial species.

Above ground dry weight biomass is estimated using equation (25) with parameter values $\alpha_{0}=-1.499, \alpha_{1}=2.148, \alpha_{2}=0.207, \alpha_{3}=-0.0281$ (Chave et al., 2005), and $\rho=0.68$ (Rahayu et al., 2006). In equations (22) and (23), we take $u_{s}$ equal to 0.262 and 0.462 for RIL and CL respectively (Sist and Saridan, 1998). Wood processing efficiency $\omega$ is assumed to be 50\% (Ministry of Forestry, 2009a). Because wood from dipterocarp trees has a relatively high wood density (Basuki et al., 2009), end-use wood is assumed to be $100 \%$ for sawn wood, with an annual oxidation rate $\delta$ of 0.02 (Winjum et al., 1998). The proportion of carbon stored in tree biomass, $\tau$, is 0.47 (IPCC, 2006).

\subsection{Voluntary Carbon Market for REDD+ Projects}

At the $16^{\text {th }}$ Conference of the Parties (CoP 16) of the UNFCCC in Cancun, it was agreed to extend the existing REDD (reducing emissions from deforestation and forest degradation) mechanism to include reducing emissions through conservation of forest carbon stocks, sustainable management of forests, and enhancement of forest carbon stocks (so-called REDD+). This decision was reaffirmed at CoP 19 in Warsaw in the 'Warsaw Framework for REDD Plus'. We study the incentives from a voluntary market for REDD+, focusing on sustainable forest management, and use the standards set by Verified Carbon Standard (VCS) as guidance for designing a carbon market in our model. VCS is a verification body that published an approved methodology for REDD+ projects (Dangerfield et al., 2013). Projects are only approved if forest management is done sustainably. With VCS, carbon credits can be obtained for avoided carbon emissions relative to a business as usual scenario. In our model, we assume that the logging company can receive carbon credits when using RIL techniques. At the end of each growth period ( $\theta=2$ years), it receives

\footnotetext{
${ }^{5}$ Source: World Bank World Development Indicators.
} 
carbon credits or pays a tax, when the amount of carbon stored is higher or lower, respectively, than the average under business as usual, see equations (21)-(24). The business as usual scenario is the CL practice with the minimum diameter harvested of $40 \mathrm{~cm}$. and optimal cutting cycle (i.e. that maximizes the LEV).

Under VCS, the minimum project duration is 20 years and the maximum project duration is 100 years (Shoch et al., 2011). As a consequence, we add the following constraint to the model for RIL practices:

$$
20 \leq T \leq 100
$$

\subsection{Solving the Model}

We solve Equation (11)-(26) for $\gamma \in\{1,2, \ldots, 51\}$ using the Excel Solver and find the value of $\gamma$ that maximizes the land expectation value by non-linear programming. To avoid local optima, we use a multi-start method that uses different starting points.

\section{RESULTS}

In this section, we first present the results on optimal cutting cycles, basal area and damages for conventional logging with a minimum diameter cutting limit of $40 \mathrm{~cm}$ and for reduced impact logging with a minimum diameter cutting limit of 40,50 and $60 \mathrm{~cm}$, in the absence of a market for carbon credits. We discuss how these results are affected by changes in assumptions on damages on residual stand and harvesting costs. Next, we introduce carbon pricing and discuss which cutting cycle and logging practice is optimal for different carbon prices, for different assumptions on damages and costs. We conclude this section with a discussion of the carbon supply curves for the different logging practices.

\subsection{Optimal Harvesting Regimes Without Carbon Prices}

We define conventional logging as the unplanned and uncontrolled logging of all commercial species $>40 \mathrm{~cm}$ DBH. Table 1 presents some characteristics of the forest resulting from the optimal cutting cycle in the absence of carbon pricing; more details can be found in Appendix 2. With conventional logging, the optimal cutting cycle is 26 years with a LEV of $256 \mathrm{USD} / \mathrm{ha}$. This felling cycle is shorter than that of the new Indonesian selective logging system issued in 2009 (new TPTI), which is 30 years. Basal areas before and after logging are 8.2 and $4.3 \mathrm{~m}^{2} /$ ha respectively. The number of trees before harvest is 185 trees/ha and the number of trees harvested is 7 trees/ha (all commercial trees with DBH $>40 \mathrm{~cm}$.) with a volume of $16.4 \mathrm{~m}^{3} / \mathrm{ha}$ and a value of $723 \mathrm{USD} / \mathrm{ha}$. This harvesting activity leads to damages on the residual stand with a value of $370 \mathrm{USD} / \mathrm{ha}$. The total number of trees after harvest is 119 trees/ha. The average amount of carbon stored in one management cycle in dry weight biomass is 31.8 ton/ha and in end-use wood products is 6.8 ton/ha. 
Table 1. Forest characteristics for optimal management under CL, RIL40, RIL50 and RIL60

\begin{tabular}{|c|c|c|c|c|}
\hline & CL & RIL40 & RIL50 & RIL60 \\
\hline Cutting cycle (years) & 26 & 30 & 26 & 22 \\
\hline Total number of trees before harvest (trees/ha) & 184.9 & 193.1 & 205.6 & 217.7 \\
\hline Total number of trees after harvest (trees/ha) & 119.4 & 120.3 & 151.9 & 179.7 \\
\hline Basal Area before harvest $\left(\mathrm{m}^{2} / \mathrm{ha}\right)$ & 8.2 & 9.0 & 10.8 & 12.9 \\
\hline Basal Area after harvest $\left(\mathrm{m}^{2} / \mathrm{ha}\right)$ & 4.3 & 4.4 & 6.8 & 9.5 \\
\hline Extracted volume $\left(\mathrm{m}^{3} / \mathrm{ha}\right)$ & 16.4 & 20.8 & 21.9 & 20.5 \\
\hline Harvest revenue (USD/ha) & 723 & 921 & 1014 & 972 \\
\hline Damage value (USD/ha) & 370 & 482 & 528 & 511 \\
\hline Forest value $^{\mathrm{a}}$ (USD/ha) & 1130 & 1332 & 1586 & 1682 \\
\hline Stock value $^{\mathrm{b}}$ (USD/ha) & 1076 & 1386 & 2253 & 3369 \\
\hline Land Expectation Value (USD/ha) & 256 & 254 & -359 & -1461 \\
\hline $\begin{array}{l}\text { Growth of commercial species in last growth period } \\
\left(\mathrm{m}^{3} / \text { ha/year }\right)\end{array}$ & 1.82 & 1.88 & 1.93 & 1.87 \\
\hline $\begin{array}{l}\text { Average growth of commercial species over cycle } \\
\left(\mathrm{m}^{3} / \text { ha/year }\right)\end{array}$ & 1.58 & 1.62 & 1.79 & 1.86 \\
\hline
\end{tabular}

${ }^{\text {a }}$ Present value of all harvests: $\boldsymbol{v}^{\prime} \boldsymbol{h}+\left(\boldsymbol{v}^{\prime} \boldsymbol{h} /\left((1+r)^{T}-1\right)\right.$

${ }^{\mathrm{b}}$ Value of stand just before harvest: $\boldsymbol{v}^{\prime} \boldsymbol{y}_{\boldsymbol{T}}$

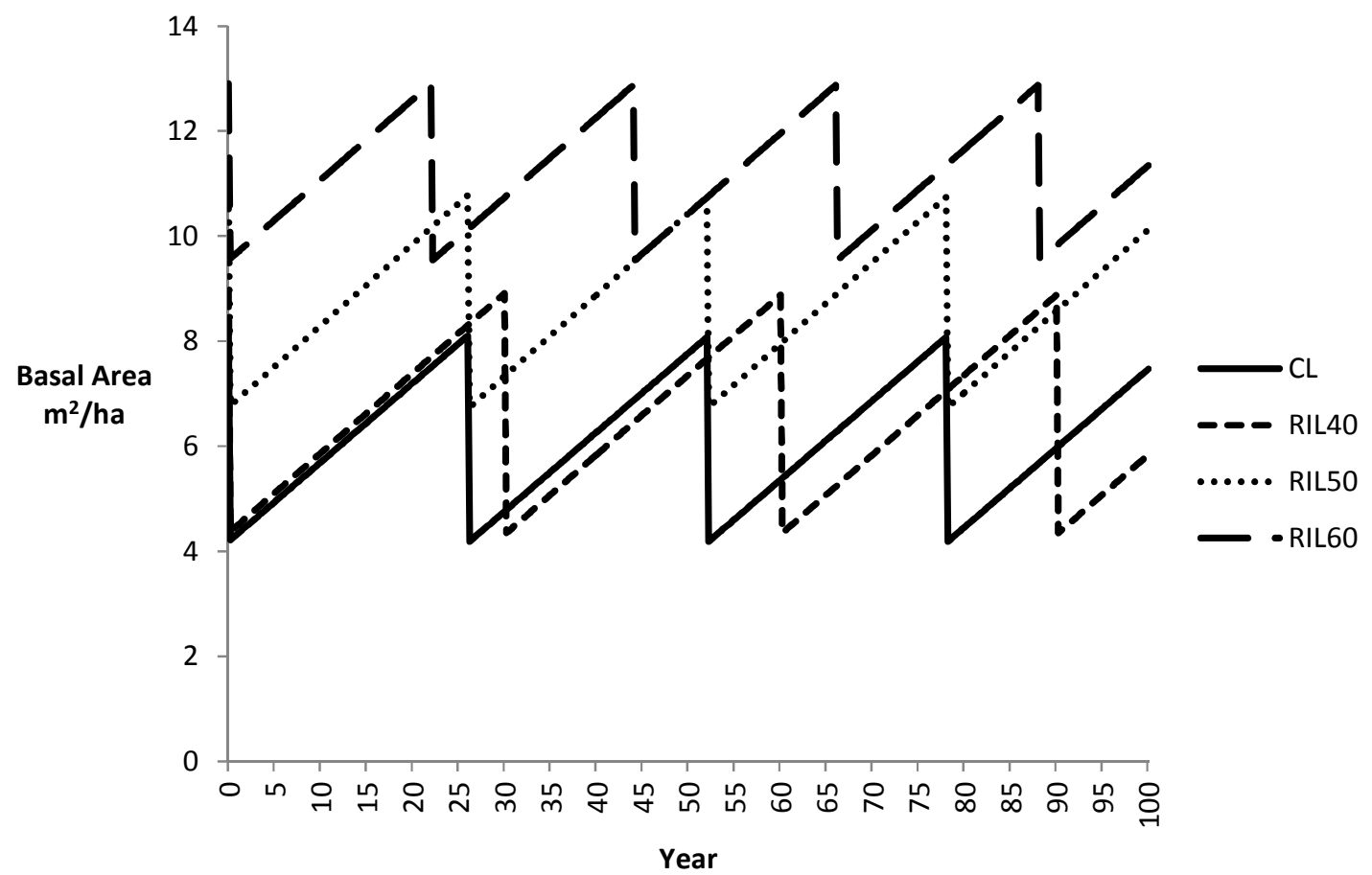

Figure 2. Basal area of steady state forests of CL, RIL40, RIL50 and RIL60 practices. 
As compared to other studies that use a matrix growth model for the tropics (Boscolo and Buongiorno, 1997; Sist et al., 2003a), the growth matrix in our study leads to a relatively low proportion of non-commercial species because of a relatively low ingrowth value. As a consequence, the stand is dominated by commercial dipterocarp and non-dipterocarp species and the optimal forest stand with CL is much thinner than the climax forest presented in Figure 1. With conventional logging, the average growth rate for commercial species is $1.5 \mathrm{~m} 3 / \mathrm{ha} /$ year.

For the case of RIL with a minimum diameter cutting limit of $40 \mathrm{~cm}$, the optimal cutting cycle is 30 years (see Table 1), which is the same as the felling cycle under the new Indonesian selective logging policy TPTI. Compared to conventional logging, the lower damage on the residual stand with RIL (as shown in the damage matrix in Appendix 2) means more trees on the residual stand and less time needed to reach the climax forest, other things being equal (Sasaki et al., 2011). The cutting cycle is longer in RIL40 than in CL because of the higher fixed cost in RIL40. Note that the LEV of RIL40 is slightly lower than that of CL (254 USD/ha and $256 \mathrm{USD} / \mathrm{ha}$ respectively). Table 1 and Appendix 2 also provide details on the forest and harvest with optimal harvesting regimes when the minimum diameter cutting limit for RIL is increased to 50 and $60 \mathrm{~cm}$. In both cases the land expectation values are negative. Hence, in the absence of carbon pricing, conventional logging is the preferred logging practice. Figure 2 presents the development of the basal area for each logging practice. The optimal cutting cycle becomes shorter as the minimum diameter harvested increases since a positive side-effect of tightening this restriction is an increase in yearly growth of the volume of commercial species.

\subsection{Optimal Forest Management with Different Cost and Damage Structures}

We are especially interested in the effects of different assumptions on the harvest-damage relation and cost on cost parameters for CL and RIL. We use detailed data on the harvest-damage relationship (see section 3.2) and cost parameters (see section 3.3). Most studies on optimal management of uneven-aged forests ignore the fact that logging causes damage to the residual stand, or model it only rudimentary. Table 2 shows that ignoring damages in the model leads to vast overestimates of the LEV. In addition, without damage, the optimal cutting cycles are much shorter. For example, ignoring damages in our model, the optimal cutting cycle for CL is 16 years with a LEV of 1470 USD/ha (cf. Ingram and Buongiorno, 1996). Obviously, since CL was the preferred logging practice even in the presence of damages, even though it leads to more damages than RIL, it is also the preferred logging practice when damages are not taken into account in the model. 
Table 2. LEV of joint production of timber and avoiding emissions from forest degradation for model without damages.

\begin{tabular}{|c|c|c|c|c|c|c|c|c|}
\hline \multirow{2}{*}{\multicolumn{2}{|c|}{$\begin{array}{l}\text { Price temporary carbon credit }\left(\mathrm{USD} / \mathrm{tCO}_{2}\right) \\
\text { Price permanent carbon credit }\left(\mathrm{USD} / \mathrm{tCO}_{2}\right)\end{array}$}} & \multirow{2}{*}{$\begin{array}{l}0 \\
0\end{array}$} & \multirow{2}{*}{$\begin{array}{l}0.2 \\
2.7 \\
\end{array}$} & \multirow{2}{*}{$\begin{array}{l}0.4 \\
5.3 \\
\end{array}$} & \multirow{2}{*}{$\begin{array}{l}0.6 \\
8.0 \\
\end{array}$} & \multirow{2}{*}{$\begin{array}{r}1 \\
13.3 \\
\end{array}$} & \multirow{2}{*}{$\begin{array}{r}2 \\
26.5 \\
\end{array}$} & \multirow{2}{*}{$\begin{array}{r}3 \\
39.8 \\
\end{array}$} \\
\hline & & & & & & & & \\
\hline \multirow[t]{4}{*}{$\mathrm{CL}$} & LEV (USD/ha) & 1470 & 1761 & 2072 & 2487 & 3472 & 7052 & 12468 \\
\hline & $\mathrm{T}^{*}$ (year) & 16 & 18 & 20 & 24 & 100 & 100 & 100 \\
\hline & Vol harvested $\left(\mathrm{m}^{3} / \mathrm{ha}\right)$ & 36 & 41 & 45.7 & 55.3 & 194.1 & 171.4 & 86.5 \\
\hline & $\mathrm{CO}_{2}$-eq (ton/ha) & 233 & 240 & 246 & 259 & 447 & 513 & 608 \\
\hline \multirow[t]{4}{*}{ RIL40 } & LEV (USD/ha) & 1369 & 1700 & 2067 & 2495 & 3864 & 7774 & 13125 \\
\hline & $\mathrm{T}^{*}$ (year) & 18 & 20 & 26 & 38 & 100 & 100 & 100 \\
\hline & Vol harvested $\left(\mathrm{m}^{3} / \mathrm{ha}\right)$ & 41.0 & 45.7 & 60.1 & 88.8 & 194.1 & 178 & 112.5 \\
\hline & $\mathrm{CO}_{2}$-eq (ton/ha) & 246 & 254 & 275 & 315 & 464 & 526 & 600 \\
\hline \multirow[t]{4}{*}{ RIL50 } & LEV (USD/ha) & -240 & 330 & 999 & 1545 & 3010 & 7712 & 13125 \\
\hline & $\mathrm{T}^{*}$ (year) & 16 & 18 & 22 & 24 & 100 & 100 & 100 \\
\hline & Vol harvested $\left(\mathrm{m}^{3} / \mathrm{ha}\right)$ & 38.4 & 43.2 & 52.8 & 57.5 & 166.6 & 166.6 & 112.5 \\
\hline & $\mathrm{CO}_{2}$-eq (ton/ha) & 333 & 340 & 355 & 362 & 528 & 528 & 600 \\
\hline \multirow[t]{4}{*}{ RIL60 } & LEV (USD/ha) & -2401 & -1581 & -749 & 95 & 1842 & 7372 & 13104 \\
\hline & $\mathrm{T}^{*}$ (year) & 14 & 14 & 16 & 18 & 24 & 100 & 100 \\
\hline & Vol harvested $\left(\mathrm{m}^{3} / \mathrm{ha}\right)$ & 33.3 & 33.3 & 37.8 & 42.2 & 54.6 & 129.5 & 108.2 \\
\hline & $\mathrm{CO}_{2}$-eq (ton/ha) & 419 & 419 & 426 & 432 & 450 & 579 & 600 \\
\hline
\end{tabular}

Table 3. LEV of joint production of timber and avoiding emissions from forest degradation with equal variable costs for CL and RIL.

\begin{tabular}{|c|c|c|c|c|c|c|c|c|}
\hline \multicolumn{2}{|c|}{ Price temporary carbon credit $\left(\mathrm{USD} / \mathrm{tCO}_{2}\right)$} & 0 & 0.2 & 0.4 & 0.6 & 1 & 2 & 3 \\
\hline \multicolumn{2}{|c|}{ Price permanent credit $\left(\mathrm{USD} / \mathrm{tCO}_{2}\right)$} & 0 & 2.7 & 5.3 & 8.0 & 13.3 & 26.5 & 39.8 \\
\hline \multirow[t]{4}{*}{$\mathrm{CL}$} & LEV (USD/ha) & 262 & 240 & 253 & 295 & 555 & 4123 & 11783 \\
\hline & $\mathrm{T}^{*}($ year $)$ & 26 & 26 & 46 & 58 & 68 & 100 & 100 \\
\hline & Vol harvested $\left(\mathrm{m}^{3} / \mathrm{ha}\right)$ & 16 & 16 & 27 & 34 & 43 & 0 & 0 \\
\hline & $\mathrm{CO}_{2}$-eq (ton/ha) & 123 & 123 & 158 & 189 & 262 & 661 & 661 \\
\hline \multirow[t]{4}{*}{ RIL40 } & LEV (USD/ha) & 260 & 276 & 333 & 438 & 774 & 4121 & 11781 \\
\hline & $\mathrm{T}^{*}($ year $)$ & 30 & 38 & 58 & 70 & 78 & 100 & 100 \\
\hline & Vol harvested $\left(\mathrm{m}^{3} / \mathrm{ha}\right)$ & 21 & 26 & 38 & 44 & 53 & 0 & 0 \\
\hline & $\mathrm{CO}_{2}$-eq (ton/ha) & 139 & 155 & 191 & 217 & 285 & 661 & 661 \\
\hline \multirow[t]{4}{*}{ RIL50 } & LEV (USD/ha) & -362 & -195 & 3 & 239 & 774 & 4121 & 11781 \\
\hline & $\mathrm{T}^{*}($ year $)$ & 26 & 32 & 46 & 60 & 78 & 100 & 100 \\
\hline & Vol harvested $\left(\mathrm{m}^{3} / \mathrm{ha}\right)$ & 22 & 26 & 36 & 45 & 53 & 0 & 0 \\
\hline & $\mathrm{CO}_{2}$-eq (ton/ha) & 192 & 203 & 229 & 253 & 285 & 661 & 661 \\
\hline \multirow[t]{4}{*}{ RIL60 } & LEV (USD/ha) & -1479 & -1139 & -769 & -374 & 542 & 4121 & 11781 \\
\hline & $\mathrm{T}^{*}($ year $)$ & 22 & 28 & 30 & 44 & 70 & 100 & 100 \\
\hline & Vol harvested $\left(\mathrm{m}^{3} / \mathrm{ha}\right)$ & 21 & 25 & 27 & 37 & 50 & 0 & 0 \\
\hline & $\mathrm{CO}_{2}$-eq (ton/ha) & 255 & 268 & 272 & 298 & 340 & 661 & 661 \\
\hline
\end{tabular}


Table 4. LEV of joint production of timber and avoiding emissions from forest degradation.

\begin{tabular}{|c|c|c|c|c|c|c|c|c|}
\hline \multirow{2}{*}{\multicolumn{2}{|c|}{$\begin{array}{l}\text { Price temporary carbon credit }\left(\mathrm{USD} / \mathrm{tCO}_{2}\right) \\
\text { Price permanent carbon credit }\left(\mathrm{USD} / \mathrm{tCO}_{2}\right)\end{array}$}} & \multirow{2}{*}{$\begin{array}{l}0 \\
0 \\
\end{array}$} & \multirow{2}{*}{$\begin{array}{l}0.2 \\
2.7 \\
\end{array}$} & \multirow{2}{*}{$\begin{array}{l}0.4 \\
5.3 \\
\end{array}$} & \multirow{2}{*}{$\begin{array}{l}0.6 \\
8.0 \\
\end{array}$} & \multirow{2}{*}{$\begin{array}{r}1 \\
13.3 \\
\end{array}$} & \multirow{2}{*}{$\begin{array}{r}2 \\
26.5 \\
\end{array}$} & \multirow{2}{*}{$\begin{array}{r}3 \\
39.8 \\
\end{array}$} \\
\hline & & & & & & & & \\
\hline \multirow[t]{4}{*}{ CL } & LEV (USD/ha) & 256 & 234 & 249 & 295 & 565 & 4276 & 11936 \\
\hline & $\mathrm{T}^{*}($ year $)$ & 26 & 26 & 46 & 60 & 68 & 100 & 100 \\
\hline & Vol harvested $\left(\mathrm{m}^{3} / \mathrm{ha}\right)$ & 16 & 16 & 27 & 34 & 43 & 0 & 0 \\
\hline & $\mathrm{CO}_{2}$-eq (ton/ha) & 123 & 127 & 165 & 192 & 262 & 661 & 661 \\
\hline \multirow[t]{4}{*}{ RIL40 } & LEV (USD/ha) & 254 & 271 & 330 & 437 & 784 & 4274 & 11934 \\
\hline & $\mathrm{T}^{*}($ year $)$ & 30 & 40 & 58 & 70 & 78 & 100 & 100 \\
\hline & Vol harvested $\left(\mathrm{m}^{3} / \mathrm{ha}\right)$ & 21 & 27 & 38 & 44 & 53 & 0 & 0 \\
\hline & $\mathrm{CO}_{2}$-eq (ton/ha) & 139 & 158 & 191 & 220 & 285 & 661 & 661 \\
\hline \multirow[t]{4}{*}{ RIL50 } & LEV (USD/ha) & -359 & -191 & 9 & 246 & 784 & 4274 & 11934 \\
\hline & $\mathrm{T}^{*}($ year $)$ & 26 & 32 & 46 & 62 & 78 & 100 & 100 \\
\hline & Vol harvested $\left(\mathrm{m}^{3} / \mathrm{ha}\right)$ & 22 & 26 & 36 & 45 & 53 & 0 & 0 \\
\hline & $\mathrm{CO}_{2}$-eq (ton/ha) & 192 & 203 & 229 & 257 & 285 & 661 & 661 \\
\hline \multirow[t]{4}{*}{ RIL60 } & LEV (USD/ha) & -1461 & -1119 & -749 & -351 & 568 & 4274 & 11934 \\
\hline & $\mathrm{T}^{*}($ year $)$ & 22 & 28 & 30 & 46 & 72 & 100 & 100 \\
\hline & Vol harvested $\left(\mathrm{m}^{3} / \mathrm{ha}\right)$ & 21 & 25 & 27 & 37 & 50 & 0 & 0 \\
\hline & $\mathrm{CO}_{2}$-eq (ton/ha) & 255 & 268 & 272 & 302 & 343 & 661 & 661 \\
\hline
\end{tabular}

Regarding cost parameters, our data indicate that variable costs for RIL are lower than those for CL, contrary to data used in previous studies (e.g. Boscolo and Buongiorno, 1997; Boscolo et al., 1997). To show the effects of differences in variable costs as compared to the case of equal variable costs for both logging practices, we show results for the case of equal variable costs in Table 3. ${ }^{6}$ Since the differences in variable costs are only minor (see Appendix 2), in the absence of carbon pricing only the LEVs are slightly affected, but optimal cutting cycles are not.

Next, we study how differences in variable costs and in damages on residual stand between logging practices affect optimal management decisions in the presence of carbon pricing.

\subsection{Carbon Pricing}

We simulate prices for temporary carbon credits of 0.2-3 USD per ton of $\mathrm{CO}_{2}$-eq. This is equivalent to prices for permanent credits of 2.7-39.8 USD per ton, which is in line with the historic minimum and maximum values for permanent permits in the European Union Emissions Trading System. The effect of a carbon price on optimal forest management is found by solving equation (22) with equation (12) to (20) and equation (27) as constraints. The simulation results are presented in Table 4. We set the results for conventional logging at the steady state in which the LEV is

\footnotetext{
${ }^{6}$ For the scenario of equal variable costs, we set variable costs equal to the average of the variable costs for CL and RIL as reported in our detailed dataset (Appendix 2).
} 
maximized from timber only (see Table 1) as our baseline. The average amount of $\mathrm{CO}_{2}$ stored in tree biomass and end-use products with CL, in the absence of carbon pricing, is 61.7 ton/ha/year.

\subsubsection{Different Costs and Damages for CL and RIL}

In Table 4, we first present results for the case of different costs and harvest-damage relations for CL and RIL, based on our detailed data. The additional amount of carbon stored under CL with REDD+, at each point in time, is the difference between the amount of carbon stored in tree biomass and wood products with CL and some positive carbon price at time $t$, and the average amount of carbon stored with CL in the absence of a carbon price in one management cycle: $C_{C L, t}-\bar{C}_{C L}{ }^{7}$ The higher the carbon price, the longer the cutting cycle. Interestingly, at low carbon prices $(p<0.6)$, the LEV goes down after the introduction of a carbon price. The reason is that a tax is paid as long as $C_{C L, t}<\bar{C}_{C L}$, which is the case in early years of each cutting cycle. Because of discounting, the net present value of the stream of carbon payments is negative for low carbon prices. With $\mathrm{CL}$, for a carbon price higher than $1.60 \mathrm{USD} / \mathrm{tCO}_{2}$ it is optimal to leave the forest untouched.

With RIL, a higher carbon price always leads to higher LEV, because harvest damages with RIL are lower than with CL, which is the logging practice in the baseline scenario. For positive carbon prices below $2 \mathrm{USD} / \mathrm{tCO}_{2}$, RIL is the preferred logging practice, based on LEV. From 2 $\mathrm{USD} / \mathrm{tCO}_{2}-$ a price equivalent to $26.50 \mathrm{USD} / \mathrm{tCO}_{2}$ for permanent certificates $-\mathrm{CL}$ gives higher LEV since from that price onwards it is optimal for all logging practices to leave the forest untouched. As a consequence, the cost disadvantage of CL in terms of harvesting costs is no longer relevant and CL's lower fixed costs make CL the preferred practice.

\subsubsection{Alternative Assumptions on Costs and Damages}

As noted before, several papers in the literature ignore that fact that the harvest-damage relation differs between logging practices. The results in Table 2 show that if we abstract from logging and skidding damages, conventional logging is the preferred logging practice for prices for temporary (2-year) credits below $0.60 \mathrm{USD} / \mathrm{tCO}_{2}$. RIL is preferred for higher prices, and - contrary to the model with damages - even for very high carbon prices. For very high carbon prices, the larger volume harvested with RIL outweighs the higher value of additional carbon stored with CL. Interestingly, the harvest volume remains high even for very high carbon prices, whereas in the presence of harvesting damages harvesting drops to zero when the maximum harvesting cycle, as allowed within the VCS standard, is reached. The intuition behind this result is that the opportunity costs for harvesting are much lower in the absence of damages. For all carbon prices, LEV is much higher in the absence of damages, though the absolute and percentage difference declines as the carbon price increases.

\footnotetext{
${ }^{7}$ The objective function for the case of conventional logging in the presence of carbon pricing is $\max _{\mathbf{y}_{T}, \mathbf{h}_{T}} L E V=\frac{\mathbf{v}_{C L}^{\prime} \mathbf{h}_{T}-F_{C L}+p \sum_{t=0}^{T-\theta}\left(C_{C L, t}-\bar{C}_{C L}\right)(1+r)^{T-t}}{(1+r)^{T}-1}-\mathbf{v}_{C L}^{\prime} \mathbf{z}_{T}+\left(C_{C L, 0}-\bar{C}_{C L}\right)$
} 


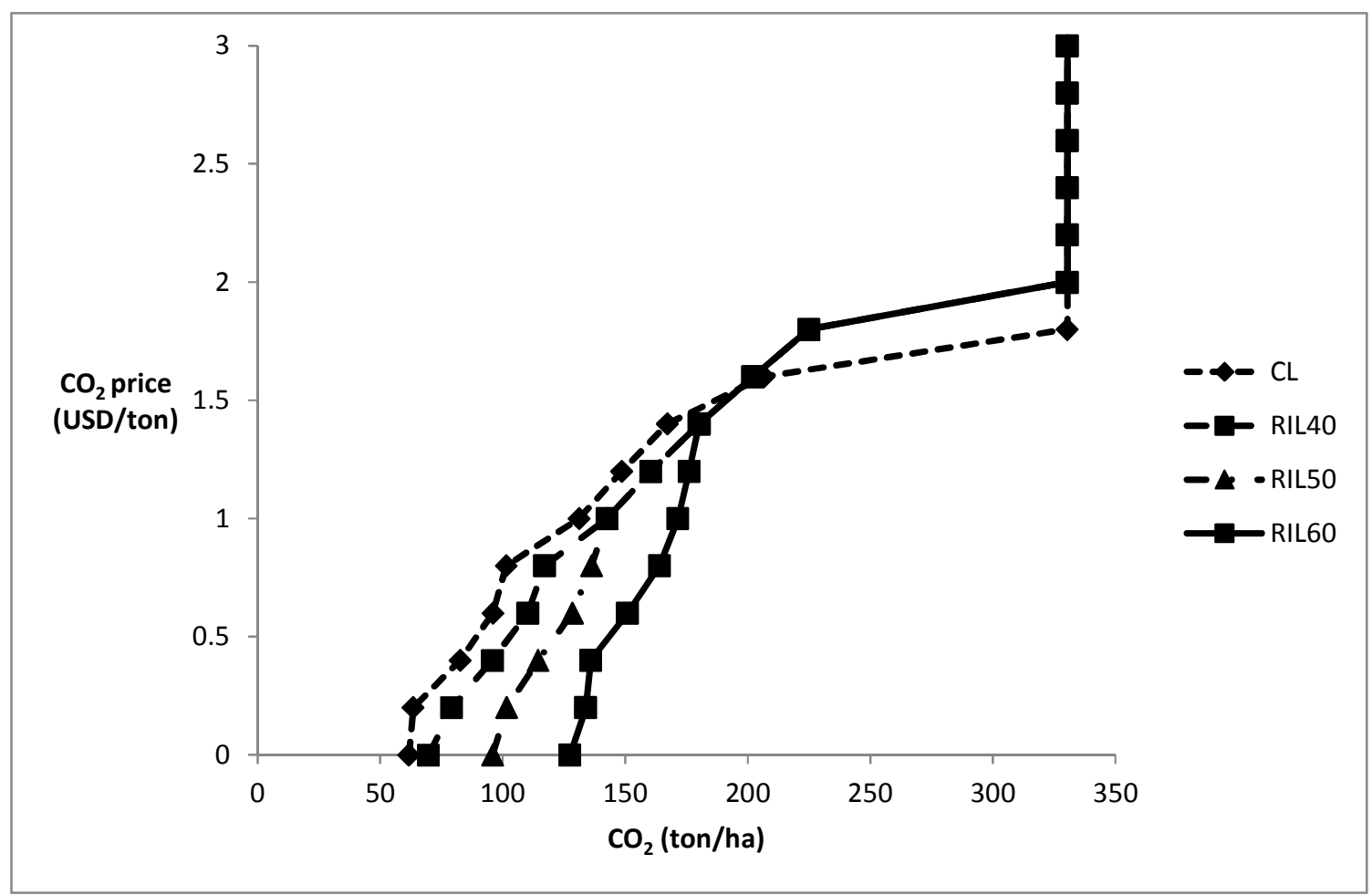

Figure 3. Supply curves of $\mathrm{CO}_{2}$ storage for different logging practices

If we ignore the fact that variable costs differ between the two logging practices, we find that our results only change quantitatively, and only to a minor extent, but not qualitatively, since according to our data the difference between variable costs are only small (see Table 3 and Appendix 2).

\subsubsection{Carbon Supply}

In Figure 3, we present carbon supply curves for different logging practices, for the case of our detailed data (i.e., lower damages and variable costs with RIL), based on the results in Table 4 and additional simulations. First, it is interesting to note that RIL is the least cost practice for carbon storage for carbon prices below $1.60 \mathrm{USD} / \mathrm{tCO}_{2}$, whereas when prices are 1.60-1.80 USD/tCO more carbon is stored with conventional logging. Since opportunity costs for harvesting are higher with RIL due to lower damages on the residual stand, higher carbon prices induces more incentives for carbon storage under CL than under RIL. Paradoxically, under REDD+ forest managers are not allowed to use CL. From 2 USD onward, the maximum cutting cycle length of 100 years and abstinence from harvesting is optimal for all logging practices, and hence the amounts of carbon stored are identical.

Without a price for reducing emissions due to sustainable forest management, switching to sustainable forest management practices (RIL40) increases carbon storage with 13\%, from 123 to $139 \mathrm{tCO}_{2}$. At a $\mathrm{CO}_{2}$ price of $0.40 \mathrm{USD}$ for 2-year temporary credits (comparable with the current 
price of permanent carbon credits in the EU ETS) this amount increases to 191 tons, which shows the large potential for increasing carbon storage through improved forest management under REDD+.

\subsubsection{Sensitivity Analysis}

In Appendix 2 we present results for a sensitivity analysis in which we use discount rates of $2 \%$ and $6 \%$. For the sake of brevity, we restrict the sensitivity analysis to scenarios based on our detailed cost and damage data. With a $2 \%$ discount rate, RIL40 is the preferred logging practice in the absence of a carbon price, contrary to our base case of a $4 \%$ discount rate. As with our base case, RIL40 is preferred for low to intermediate carbon prices, while CL is again preferred for high carbon prices. The result that LEV decreases for low carbon prices relative to the case of a zero carbon price, disappears, confirming the role of the discount rate in this effect. With a $6 \%$ discount rate, the preferred logging practice is the same as with our base case for zero to intermediate carbon prices. For high carbon prices, the difference in LEV between logging practices becomes negligible.

\section{CONCLUSIONS}

We analyzed the effects of differences in residual stand damage and harvesting costs for conventional logging and reduced impact logging on the respective optimal cutting cycles and land expectation values. We applied the Faustmann model, extended for remuneration for additional carbon sequestration stemming from sustainable forest management (REDD+), to detailed data on a tropical forest concession in East-Kalimantan.

There are three main findings in our paper. First, we find that ignoring damages on the residual stand in the model leads to vast overestimates of LEV and, for low carbon prices, overestimates of the optimal cutting cycle. Second, for positive carbon prices below $2 \mathrm{USD} / \mathrm{tCO}_{2}$, reduced impact logging is the preferred logging practice in terms of LEV. However, from 2 $\mathrm{USD} / \mathrm{tCO}_{2}$ onward, $\mathrm{CL}$ is preferred since from that price onwards it is optimal for all logging practices to leave the forest untouched, and fixed costs are lower for CL. Third, we find that conventional logging is the least cost practice for carbon storage for a range of carbon prices. However, this logging practice cannot be used when applying for carbon credits under REDD+.

We find that the recent cutting cycle determined by the Ministry of Forestry in Indonesia (i.e. 30 years) is longer than the optimal cutting cycle for conventional logging, but appropriate for reduced impact logging with minimum diameter cutting limit of $40 \mathrm{~cm}$. In addition, our study suggests that switching from conventional logging to reduced impact logging can significantly reduce carbon emissions, even at low carbon prices, while still producing commercial timber important for employment in the sawmill and manufacturing industries - for low to intermediate carbon prices. Indeed, at a carbon price of $2 \mathrm{USD} / \mathrm{tCO}_{2}$ for 2 -year temporary credits (equivalent to 26.5 USD for permanent credits), it is optimal to leave the forest undisturbed for all logging practices. 


\section{References}

Basuki, T.M., van Laake, P.E., Skidmore, A.K., Hussin, Y.A., 2009. Allometric equations for estimating the above-ground biomass in tropical lowland Dipterocarp forests. Forest Ecology and Management 257, 1684-1694.

Bertault, J.G., Sist, P., 1997. An experimental comparison of different harvesting intensities with reduced-impact and conventional logging in East Kalimantan, Indonesia. Forest Ecology and Management 94, 209-218.

Bollandsas, O.M., Buongiorno, J., Gobakken, T., 2008. Predicting the growth of stands of trees of mixed species and size: A matrix model for Norway. Scandinavian Journal of Forest Research 23, 167-178.

Boltz, F., Carter, D.R., Holmes, T.P., Pereira, R., 2001. Financial returns under uncertainty for conventional and reduced-impact logging in permanent production forests of the Brazilian Amazon. Ecological Economics 39, 387-398.

Boltz, F., Holmes, T.P., Carter, D.R., 2003. Economic and environmental impacts of conventional and reduced-impact logging in tropical South America: a comparative review. Forest Policy Econ 5, 69-81.

Boscolo, M., Buongiorno, J., 1997. Managing a tropical rainforest for timber, carbon storage and tree diversity. Commonwealth Forestry Review 76, 246-254.

Boscolo, M., Buongiorno, J., Panayotou, T., 1997. Simulating options for carbon sequestration through improved management of a lowland tropical rain forest. Environment and Development Economics 2, 241 - 263.

Boscolo, M., Vincent, J.R., 2000. Promoting better logging practices in tropical forests: a simulation analysis of alternative regulations. Land Economics 76, 1-14.

Buongiorno, J., Dahir, S., Lu, H.-C., Lin, C.-R., 1994. Tree size diversity and economic returns in uneven-aged forest stands. Forest Science 40, 83-103.

Buongiorno, J., Holvorsen, E.A., Bollandsas, O.M., Gobakken, T., Hofstad, O., 2012. Optimizing management regimes for carbon storage and other benefits in uneven-aged stands dominated by Norway spruce, with a derivation of the economic supply of carbon storage. Scandinavian Journal of Forest Research, 1-14.

Buongiorno, J., Lu, H.-C., 1990. Economic stocking and cutting cycle in a regulated selection forest. Forest Ecology and Management32, 203-216.

Buongiorno, J., Michie, B.R., 1980. A Matrix Model of Uneven-Aged Forest Management. Forest Science 26, 609-625.

Buongiorno, J., Peyron, J.L., Houllier, F., Bruciamacchie, M., 1995. Growth and Management of Mixed-Species, Uneven-Aged Forests in the French Jura - Implications for Economic Returns and Tree Diversity. Forest Science 41, 397-429.

Chang, S.J., 1981. Determination of the Optimal Growing Stock and Cutting Cycle for an UnevenAged Stand. Forest Science 27, 739-744.

Chave, J., Andalo, C., Brown, S., Cairns, M.A., Chambers, J.Q., Eamus, D., Folster, H., Fromard, F., Higuchi, N., Kira, T., Lescure, J.P., Nelson, B.W., Ogawa, H., Puig, H., Riera, B., 
Yamakura, T., 2005. Tree allometry and improved estimation of carbon stocks and balance in tropical forests. Oecologia 145, 87-99.

Dangerfield, M., Wilson, C., Pearson, T., Schultz, J., 2013. Methodology for Improved Forest Management: Conversion from Logged to Protected Forest. Approved VCS Methodology VM 0010, Version 1.2.

Dwiprabowo, H., Grulois, S., Sist, P., Kartawinata, K., 2002. Reduced impact logging studies constituting a developmental phase within a long term research strategy in Bulungan research forest, East Kalimantan, Technical report phase I 1997-2001 ITTO Project PD 12/97 Rev.1 (F) Forest, Science and Sustainability: The Bulungan model forest. CIFOR, Bogor Indonesia.

Enggelina, A., 1998. Volume equation, in: Bertault, J.-G., Kadir, K. (Eds.), Silvicultural research in a lowland mixed dipterocarp forest of East Kalimantan. CIRAD-FORDA-PT Inhutani I.

Galinato, G.I., Uchida, S., 2011. The Effect of Temporary Certified Emission Reductions on Forest Rotations and Carbon Supply. Canadian Journal of Agricultural Economics 59, 145-164.

Hartman, R., 1976. Harvesting Decision When a Standing Forest Has Value. Economic Inquiry 14, 52-58

Holmes, T.P., Blate, G.M., Zweede, J.C., Rodrigo Pereira, J., Barreto, P., Boltz, F., Bauch, R., 2000. Financial costs and benefits of reduced-impact logging relative to conventional logging in the Eastern Amazon. Tropical Forest Foundation, Washington DC.

Ingram, C.D., Buongiorno, J., 1996. Income and diversity tradeoffs from management mixed lowland dipterocarps in Malaysia. Journal of Tropical Forest Science 9, 242-270.

IPCC, 2006. IPCC Guideline 2006 Guidelines for national green house gas inventories. IPCC.

Krisnawati, H., Suhendang, E., Parthama, I.P., 2008. Transition matrix growth models for logged over natural forest in Central Kalimantan. Jurnal Penelitian Hutan dan Konservasi Alam 5, 107-128.

Macpherson, A.J., Schulze, M.D., Carter, D.R., Vidal, E., 2010. A Model for comparing reduced impact logging with conventional logging for an Eastern Amazonian Forest. Forest Ecology and Management 260, 2002-2011.

Medjibe, V.P., Putz, F.E., 2012. Cost comparisons of reduced-impact and conventional logging in the tropics. Journal of Forest Economics 18, 242-256.

Ministry of Forestry, 2009a. Peraturan Dirjen Bina Produksi Kehutanan No P.13/VI-BPPHH/2009, tentang Rendemen Kayu Olahan Industri Primer Hasil Hutan Kayu (IPHHK), Jakarta.

Ministry of Forestry, 2009b. Peraturan Menteri Kehutanan Nomor: P.11/Menhut-II/2009 tentang Sistem silvikultur dalam areal izin usaha pemanfaatan hasil hutan kayu pada hutan produksi. Kementerian Kehutanan, Jakarta.

Olschewski, R., Benitez, P.C., 2010. Optimizing joint production of timber and carbon sequestration of afforestation projects. Journal of Forest Economics 16, 1-10.

Pinard, M.A., Putz, F.E., 1996. Retaining forest biomass by reducing logging damage. Biotropica 28, 278-295. 
Priyadi, H., Sist, P., Gunarso, P., Kanninen, M., Kartawinata, K., Sheil, D., Setyawati, T., Dwiprabowo, H., Siswoyo, H., Silooy, G., Siregar, C.A., Dharmawan, W.S., 2007. Reduced Impact Logging: Benefits and Constraints, in: Gunarso, P., Setyawati, T., Sunderland, T., Shackleton, C. (Eds.), Managing Forest Resources in A Decentralized Environment: Lessons learnt from the Malinau Forest, East Kalimantan, Indonesia. CIFOR, Bogor Indonesia.

PT Sumalindo Lestari Jaya, 2008. Proposal teknis permohonan ijin usaha pemanfaatan hasil hutan kayu pada hutan alam. PT Sumalindo Lestari Jaya, Jakarta.

Putz, F.E., Pinard, M.A., 1993. Reduced-Impact Logging as a Carbon-Offset Method. Conserv Biol 7, 755-757.

Putz, F.E., Sist, P., Fredericksen, T., Dykstra, D., 2008a. Reduced-impact logging: Challenges and opportunities. Forest Ecology and Management 256, 1427-1433.

Putz, F.E., Zuidema, P.A., Pinard, M.A., Boot, R.G.A., Sayer, J.A., Sheil, D., Sist, P., Elias, Vanclay, J.K., 2008b. Improved tropical forest management for carbon retention. Plos Biology 6, 1368-1369.

Rahayu, S., Lusiana, B., Noordwijk, M.v., 2006. Pendugaan cadangan karbon di atas permukaan tanah pada berbagai sistem penggunaan lahan di Kabupaten Nunukan, Kalimantan Timur, in: Lusiana, B., Noordwijk, M.v., Rahayu, S. (Eds.), Cadangan karbon di Kabupaten Nunukan, Kalimantan Timur: monitoring secara spasial dan pemodelan. Laporan tim proyek pengelolaan sumberdaya alam untuk penyimpanan karbon (formacs). World Agroforestry Center, Bogor Indonesia.

Samsoedin, I., Dharmawan, I.W.S. and Siregar, C.A. 2009 Carbon biomass potency of old growth forest and thirty year-old logged over forest in Malinau Research Forest, East Kalimantan. Jurnal Penelitian Hutan dan Konservasi Alam, VI (1), 47-56.

Sasaki, N., Asner, G.P., Knorr, W., Durst, P.B., Priyadi, H.R., Putz, F.E., 2011. Approaches to classifying and restoring degraded tropical forests for the anticipated REDD plus climate change mitigation mechanism. Iforest 4, 1-6.

Sasaki, N., Chheng, K., Ty, S., 2012. Managing production forests for timber production and carbon emission reductions under the REDD+ scheme. Environmental Science and Policy 23, 3544.

Shoch, D., Eaton, J., Settelmyer, S., 2011. Project Developer's Guidebook to VCS REDD Methodologies. Conservation International.

Sist, P., Nolan, T., Bertault, J.G., Dykstra, D., 1998. Harvesting intensity versus sustainability in Indonesia. Forest Ecology and Management108, 251-260.

Sist, P., Picard, N., Gourlet-Fleury, S., 2003a. Sustainable cutting cycle and yields in a lowland mixed dipterocarp forest of Borneo. Annals of Forest Science 60, 803-814.

Sist, P., Saridan, A., 1998. Description of the primary lowland forest of Berau. Silvicultural research in a lowland mixed dipterocarp forest of East Kalimantan, the contribution of STREK project. Jakarta. 
Sist, P., Sheil, D., Kartawinata, K., Priyadi, H., 2003b. Reduced-impact logging in Indonesian Borneo: some results confirming the need for new silvicultural prescriptions. Forest Ecology and Management 179, 415-427.

Tassone, V.C., Wesseler, J., Nesci, F.S., 2004. Diverging incentives for afforestation from carbon sequestration: an economic analysis of the EU afforestation program in the south of Italy. Forest Policy and Economics 6, 567-578.

van Kooten, G.C., Binkley, C.S., Delcourt, G., 1995. Effect of Carbon Taxes and Subsidies on Optimal Forest Rotation Age and Supply of Carbon Services. American Journal of Agricultural Economics 77, 365-374.

Vanclay, J.K., 1994. Modelling forest growth and yield: applications to mixed tropical forests. CAB International.

Winjum, J.K., Brown, S., Schlamadinger, B., 1998. Forest harvests and wood products: Sources and sinks of atmosphere carbon dioxide. Forest Science 44, 272-284.

Zimmerman, B.L., Kormos, C.F., 2012. Prospects for Sustainable Logging in Tropical Forests. Bioscience 62, 479-487. 


\section{Appendix 1. Data for forest growth model}

$\left[\begin{array}{ccccccccccccc}\multicolumn{10}{c}{\boldsymbol{A}_{\boldsymbol{I}}=} \\ 0,80 & 0 & 0 & 0 & 0 & 0 & 0 & 0 & 0 & 0 & 0 & 0 & 0 \\ 0,16 & 0,79 & 0 & 0 & 0 & 0 & 0 & 0 & 0 & 0 & 0 & 0 & 0 \\ 0 & 0,17 & 0,79 & 0 & 0 & 0 & 0 & 0 & 0 & 0 & 0 & 0 & 0 \\ 0 & 0 & 0,18 & 0,78 & 0 & 0 & 0 & 0 & 0 & 0 & 0 & 0 & 0 \\ 0 & 0 & 0 & 0,19 & 0,78 & 0 & 0 & 0 & 0 & 0 & 0 & 0 & 0 \\ 0 & 0 & 0 & 0 & 0,19 & 0,78 & 0 & 0 & 0 & 0 & 0 & 0 & 0 \\ 0 & 0 & 0 & 0 & 0 & 0,20 & 0,78 & 0 & 0 & 0 & 0 & 0 & 0 \\ 0 & 0 & 0 & 0 & 0 & 0 & 0,19 & 0,79 & 0 & 0 & 0 & 0 & 0 \\ 0 & 0 & 0 & 0 & 0 & 0 & 0 & 0,19 & 0,79 & 0 & 0 & 0 & 0 \\ 0 & 0 & 0 & 0 & 0 & 0 & 0 & 0 & 0,18 & 0,80 & 0 & 0 & 0 \\ 0 & 0 & 0 & 0 & 0 & 0 & 0 & 0 & 0 & 0,17 & 0,81 & 0 & 0 \\ 0 & 0 & 0 & 0 & 0 & 0 & 0 & 0 & 0 & 0 & 0,16 & 0,82 & 0 \\ 0 & 0 & 0 & 0 & 0 & 0 & 0 & 0 & 0 & 0 & 0 & 0,14 & 0,95\end{array}\right]$

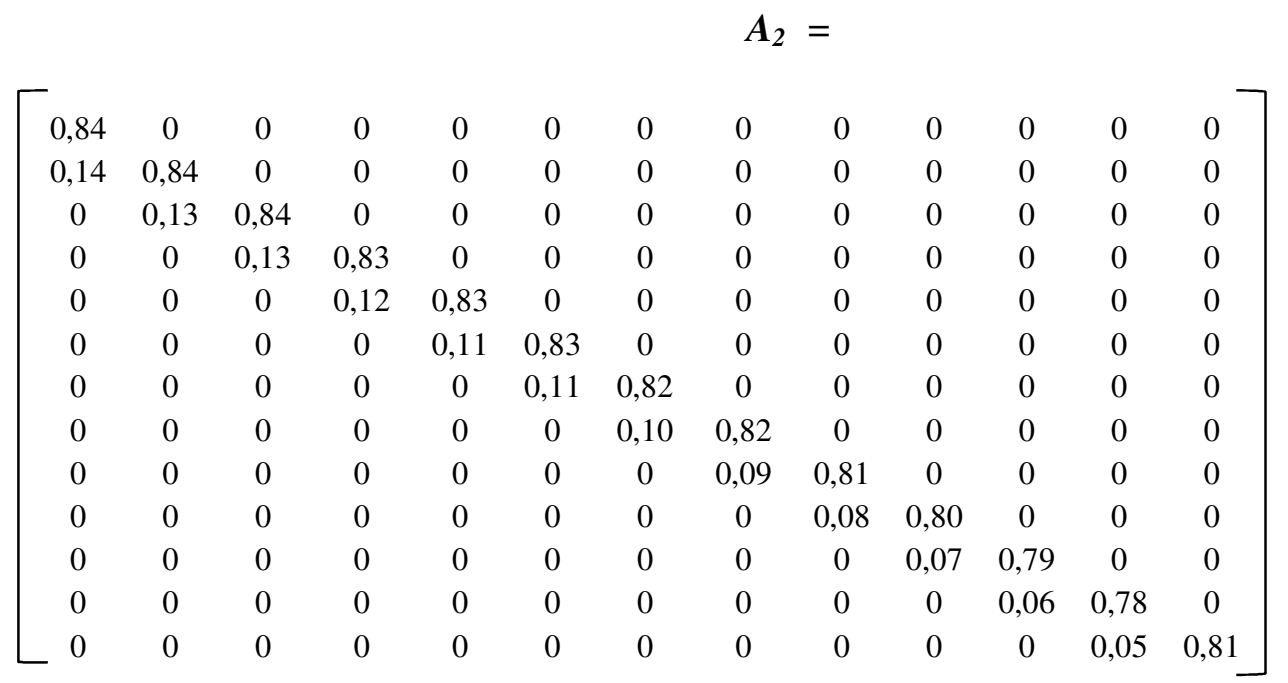




$$
A_{3}=
$$

$\left[\begin{array}{ccccccccccccc}0,81 & 0 & 0 & 0 & 0 & 0 & 0 & 0 & 0 & 0 & 0 & 0 & 0 \\ 0,13 & 0,81 & 0 & 0 & 0 & 0 & 0 & 0 & 0 & 0 & 0 & 0 & 0 \\ 0 & 0,13 & 0,81 & 0 & 0 & 0 & 0 & 0 & 0 & 0 & 0 & 0 & 0 \\ 0 & 0 & 0,12 & 0,81 & 0 & 0 & 0 & 0 & 0 & 0 & 0 & 0 & 0 \\ 0 & 0 & 0 & 0,12 & 0,81 & 0 & 0 & 0 & 0 & 0 & 0 & 0 & 0 \\ 0 & 0 & 0 & 0 & 0,11 & 0,81 & 0 & 0 & 0 & 0 & 0 & 0 & 0 \\ 0 & 0 & 0 & 0 & 0 & 0,11 & 0,81 & 0 & 0 & 0 & 0 & 0 & 0 \\ 0 & 0 & 0 & 0 & 0 & 0 & 0,10 & 0,81 & 0 & 0 & 0 & 0 & 0 \\ 0 & 0 & 0 & 0 & 0 & 0 & 0 & 0,10 & 0,81 & 0 & 0 & 0 & 0 \\ 0 & 0 & 0 & 0 & 0 & 0 & 0 & 0 & 0,09 & 0,81 & 0 & 0 & 0 \\ 0 & 0 & 0 & 0 & 0 & 0 & 0 & 0 & 0 & 0,09 & 0,81 & 0 & 0 \\ 0 & 0 & 0 & 0 & 0 & 0 & 0 & 0 & 0 & 0 & 0,08 & 0,80 & 0 \\ 0 & 0 & 0 & 0 & 0 & 0 & 0 & 0 & 0 & 0 & 0 & 0,08 & 0,88\end{array}\right]$

The ingrowth matrices $\mathbf{R}_{i k}$ only contain nonzero values on the first row. For the sake of brevity, we omit the remaining rows.

$\left[\begin{array}{lllllllllllll}\multicolumn{1}{c}{\mathbf{R}_{11}=} \\ 0.0103 & 0.0102 & 0.0099 & 0.0097 & 0.0093 & 0.0090 & 0.0085 & 0.0080 & 0.0075 & 0.0069 & 0.0062 & 0.0055 & 0.0047\end{array}\right]$

$\left.\begin{array}{ccccccccccccc}\multicolumn{1}{c}{\mathbf{R}_{12}=} \\ -0.0002 & -0.0003 & -0.0006 & -0.0008 & -0.0012 & -0.0015 & -0.0020 & -0.0025 & -0.0030 & -0.0036 & -0.0043 & -0.0050 & -0.0058\end{array}\right]$

$\mathbf{R}_{13}=$

$\left[\begin{array}{lllllllllllll}-0.0002 & -0.0003 & -0.0006 & -0.0008 & -0.0012 & -0.0015 & -0.0020 & -0.0025 & -0.0030 & -0.0036 & -0.0043 & -0.0050 & -0.0058\end{array}\right]$

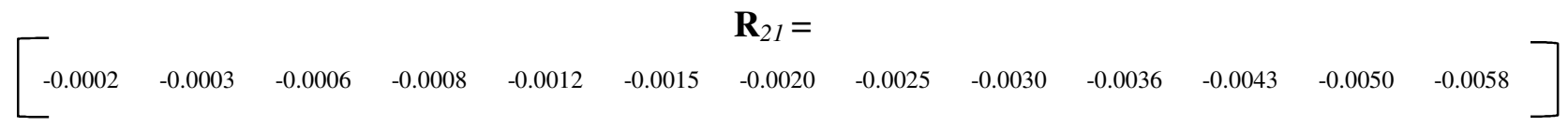

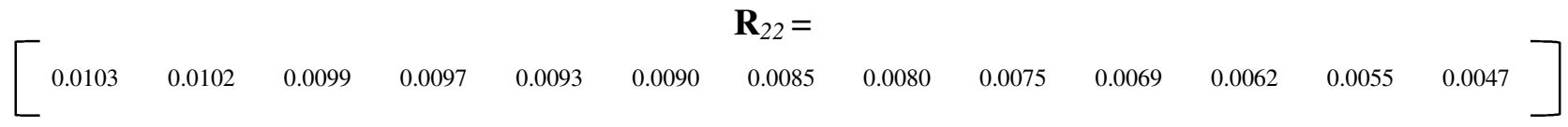




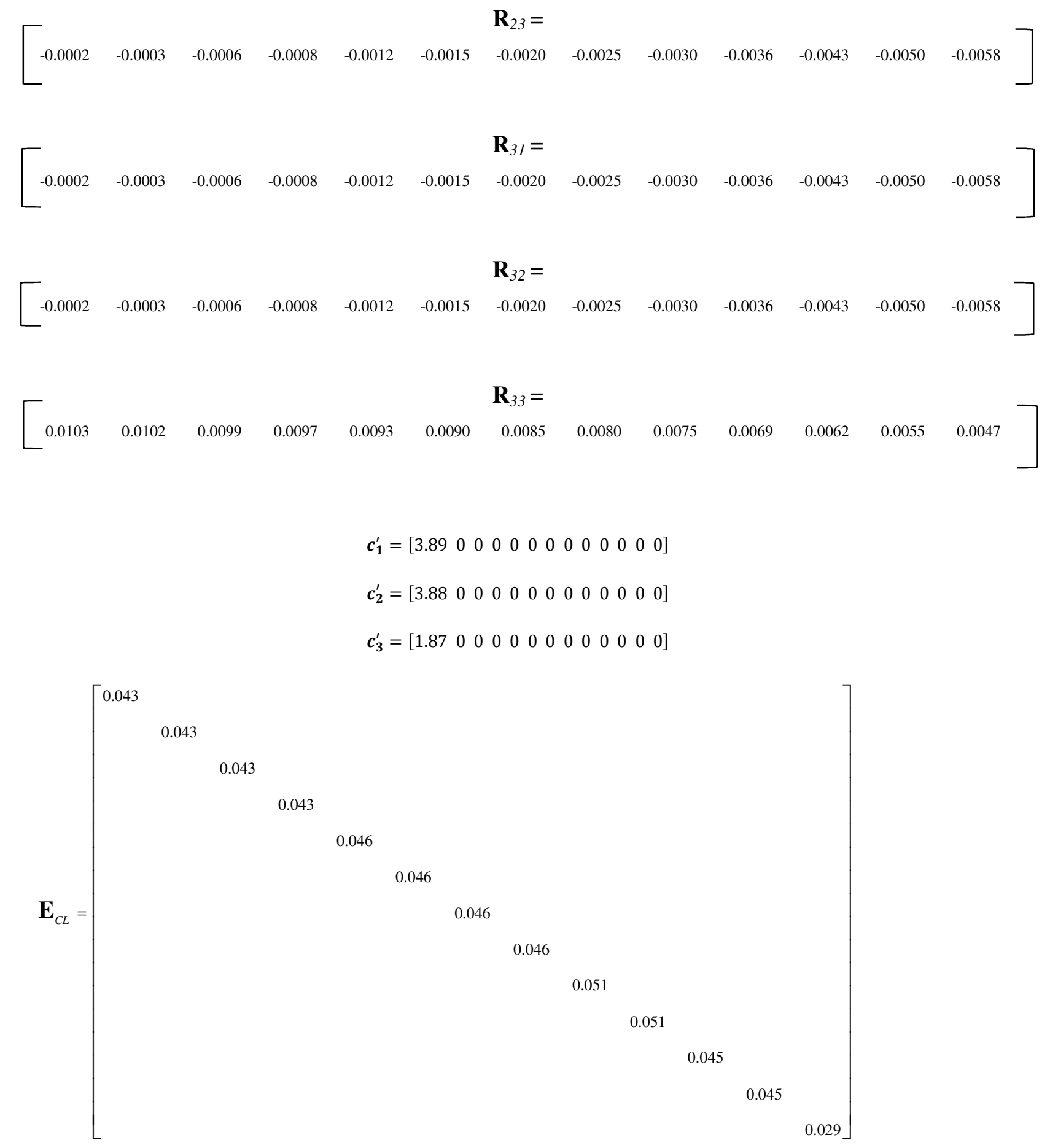




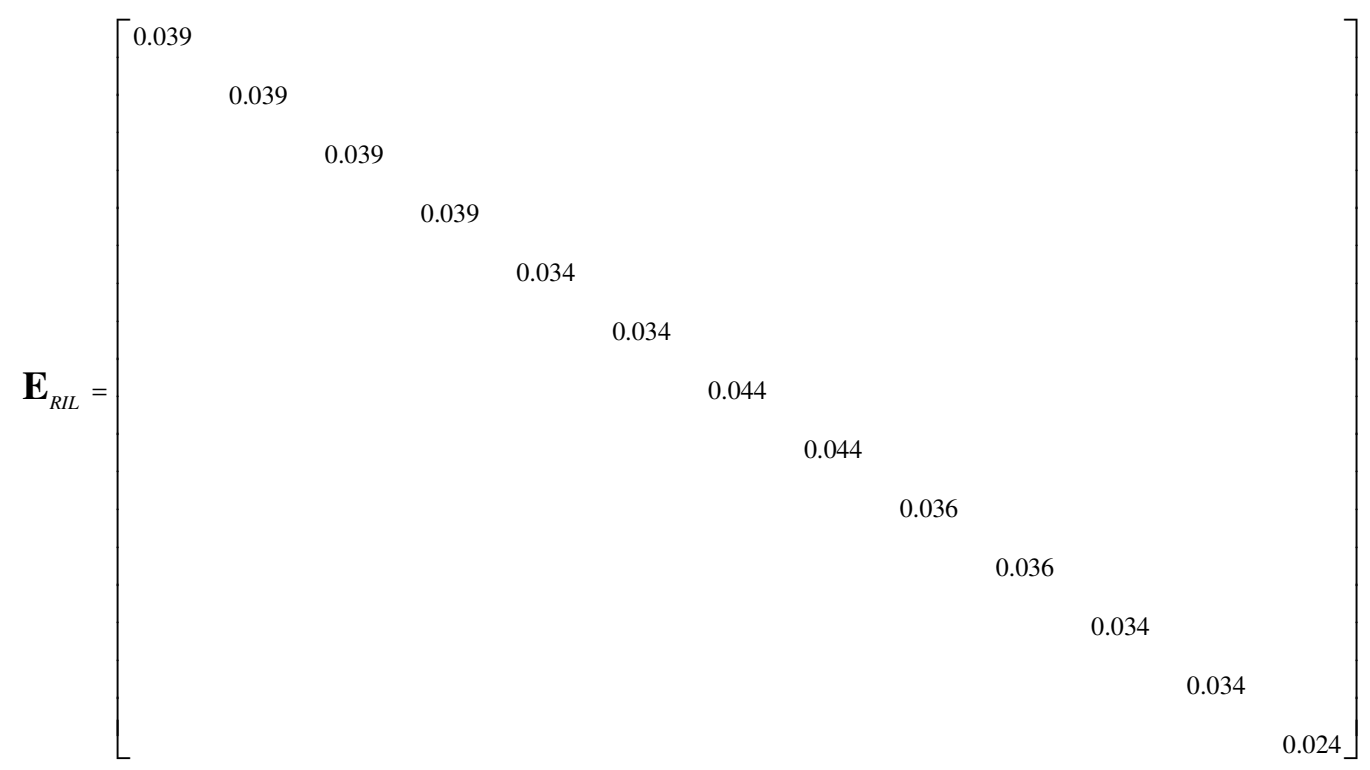




\section{Appendix 2. Additional Tables}

Table A2.1. Economic parameters, all values in 2012 US dollars.

\begin{tabular}{|c|c|c|c|}
\hline & CL & RIL & Source \\
\hline \multicolumn{4}{|l|}{ Fixed costs (in USD/ha) } \\
\hline$\underline{\text { Administration and investment }}$ & & & PT Sumalindo Lestari Jaya (2008) \\
\hline Environmental Impact Assessment (EIA) & 0.37 & 0.37 & \\
\hline Technical Proposal & 0.12 & 0.12 & \\
\hline Working area Definition & 0.12 & 0.12 & \\
\hline Recommendation from Bupati/Gubernur & 0.37 & 0.37 & \\
\hline Building & 22.77 & 22.77 & \\
\hline Forest protection & 3.96 & 3.96 & \\
\hline Transportation & 17.76 & 17.76 & \\
\hline Machineries & 218.08 & 304.19 & \\
\hline Office & 2.88 & 2.88 & \\
\hline Supporting equipment & 9.38 & 9.38 & \\
\hline Pre harvesting & & & Dwiprabowo et al.(2002) \\
\hline Timber inventory and contour survey & 10.06 & 13.92 & \\
\hline Data entry and block mapping & 1.00 & 1.31 & \\
\hline Data checking and mapping & & 0.44 & \\
\hline Skidtrail marking and checking & & 0.95 & \\
\hline ROADENG software purchase & & 0.23 & \\
\hline Vine cutting & & 0.81 & \\
\hline \multicolumn{4}{|l|}{ Tax } \\
\hline Concession license fee (IUPHHK) & 5.34 & 5.34 & \\
\hline Building tax & 4.64 & 4.64 & \\
\hline Total & 297 & 390 & \\
\hline \multicolumn{4}{|l|}{ Variable costs (in USD/m ${ }^{3}$ ) } \\
\hline \multicolumn{4}{|l|}{$\underline{\text { Production }}$} \\
\hline Training & & 0.47 & Dwiprabowo et al. (2002) \\
\hline Supervision & 0.12 & 0.24 & \\
\hline Felling & 0.42 & 0.42 & \\
\hline Skidding & 6.09 & 4.41 & \\
\hline Log landing opening & 0.11 & 0.08 & \\
\hline Road construction and maintenance & 7.90 & 7.90 & \\
\hline Log transport & 31.80 & 31.80 & \\
\hline Total & 46.4 & 44.8 & \\
\hline
\end{tabular}

(Table continues on next page) 
Table A2.1. Economic parameters, all values in 2012 US dollars (continued).

\begin{tabular}{lrrl}
\hline & CL & RIL & Source \\
\hline Taxes and prices & & & \\
Royalty Tax Dipterocarp* & 13.7 & 13.7 & Gov't Regulation No 51/1998 \\
Royalty Tax non Dipterocarp* & 10.3 & 10.3 & Gov't Regulation No 51/1998 \\
Reforestation Fund (DR) Dipterocarp & 16 & 16 & Presidential Decree No 40/1993 \\
Reforestation Fund (DR) non Dipterocarp & 13 & 13 & Presidential Decree No 40/1993 \\
Price Dipterocarp (USD/m ${ }^{3}$ ) & 137 & 137 & Min. of Trade Decree No 22/2012 \\
Price non Dipterocarp (USD $/ \mathrm{m}^{3}$ ) & 103 & 103 & Min. of Trade Decree No 22/2012 \\
Net price Dipterocarp (USD/m ${ }^{3}$ )** & 60 & 61 & \\
Net price Dipterocarp (USD/m $\left.{ }^{3}\right)^{* *}$ & 32 & 34 & \\
Discount rate & $4 \%$ & $4 \%$ & \\
& & &
\end{tabular}

* Ministry of Trade Decree No 22/2012 (royalty tax is $10 \%$ of the standard price determined by the government).

** Price after taxes and variable costs; elements of $\boldsymbol{v}_{\boldsymbol{s}}$.

Table A2.2. Predicted stand state in the steady state condition with no harvest

\begin{tabular}{|c|c|c|c|c|}
\hline \multirow{2}{*}{$\begin{array}{l}\text { Diameter } \\
(\mathrm{cm})\end{array}$} & \multicolumn{3}{|c|}{ N/ha } & \multirow{2}{*}{ Total } \\
\hline & Dipterocarp & Non Dipterocarp & Non Commercial & \\
\hline $10-14$ & 24.85 & 28.84 & 9.69 & 63.4 \\
\hline $15-19$ & 18.71 & 24.57 & 6.81 & 50.1 \\
\hline $20-24$ & 14.94 & 20.03 & 4.60 & 39.6 \\
\hline $25-29$ & 12.47 & 15.43 & 2.97 & 30.9 \\
\hline $30-34$ & 10.77 & 11.09 & 1.84 & 23.7 \\
\hline $35-39$ & 9.53 & 7.33 & 1.09 & 17.9 \\
\hline $40-44$ & 8.57 & 4.39 & 0.62 & 13.6 \\
\hline $45-49$ & 7.78 & 2.35 & 0.33 & 10.5 \\
\hline $50-54$ & 7.07 & 1.10 & 0.17 & 8.3 \\
\hline $55-59$ & 6.39 & 0.44 & 0.08 & 6.9 \\
\hline $60-64$ & 5.69 & 0.15 & 0.04 & 5.9 \\
\hline $65-69$ & 4.93 & 0.04 & 0.02 & 5.0 \\
\hline$\geq 70$ & 14.77 & 0.01 & 0.01 & 14.8 \\
\hline Population (N/ha) & 146.4 & 115.8 & 28.3 & 290.5 \\
\hline Basal Area $\left(\mathrm{m}^{2} / \mathrm{ha}\right)$ & 19.4 & 5.8 & 1.1 & 26.4 \\
\hline Volume $\left(\mathrm{m}^{3} / \mathrm{ha}\right)$ & 270 & 51 & 9 & 330 \\
\hline Carbon stored in biomass (ton/ha) & 196.02 & 46.34 & 8.65 & 251 \\
\hline
\end{tabular}


Table A2.3. Predicted above ground biomass, root biomass, and carbon stored in biomass in dipterocarp, non-dipterocarp and non-commercial species

\begin{tabular}{ccccccc}
\hline \multirow{2}{*}{$\begin{array}{c}\text { Diameter } \\
(\mathrm{cm})\end{array}$} & \multicolumn{2}{c}{ Dipterocarp } & \multicolumn{2}{c}{ Non Dipterocarp } & \multicolumn{2}{c}{ Non-commercial } \\
\cline { 2 - 6 } & $\begin{array}{c}\text { AGB } \\
\text { (ton /tree) }\end{array}$ & $\begin{array}{c}\text { C stock } \\
\text { (ton /tree) }\end{array}$ & $\begin{array}{c}\text { AGB } \\
\text { (ton /tree) }\end{array}$ & $\begin{array}{c}\text { C stock } \\
\text { (ton /tree) }\end{array}$ & $\begin{array}{c}\text { AGB } \\
\text { (ton /tree) }\end{array}$ & $\begin{array}{c}\text { C stock } \\
\text { (ton /tree) }\end{array}$ \\
\hline $10-14$ & 0.082 & 0.039 & 0.082 & 0.039 & 0.082 & 0.039 \\
$15-19$ & 0.200 & 0.094 & 0.200 & 0.094 & 0.200 & 0.094 \\
$20-24$ & 0.388 & 0.183 & 0.388 & 0.183 & 0.388 & 0.183 \\
$25-29$ & 0.655 & 0.308 & 0.655 & 0.308 & 0.655 & 0.308 \\
$30-34$ & 1.009 & 0.474 & 1.009 & 0.474 & 1.009 & 0.474 \\
$35-39$ & 1.454 & 0.683 & 1.454 & 0.683 & 1.454 & 0.683 \\
$40-44$ & 1.995 & 0.938 & 1.995 & 0.938 & 1.995 & 0.938 \\
$45-49$ & 2.636 & 1.239 & 2.636 & 1.239 & 2.636 & 1.239 \\
$50-54$ & 3.378 & 1.587 & 3.378 & 1.587 & 3.378 & 1.587 \\
$55-59$ & 4.222 & 1.984 & 4.222 & 1.984 & 4.222 & 1.984 \\
$60-64$ & 5.171 & 2.430 & 5.171 & 2.430 & 5.171 & 2.430 \\
$65-69$ & 6.223 & 2.925 & 6.223 & 2.925 & 6.223 & 2.925 \\
$\geq 70$ & 7.380 & 3.469 & 7.380 & 3.469 & 7.380 & 3.469 \\
\hline
\end{tabular}

Table A2.4. Estimated wood volume and basal area of dipterocarp, non-dipterocarp and noncommercial species

\begin{tabular}{ccccccc}
\hline \multirow{2}{*}{$\begin{array}{c}\text { Diameter } \\
(\mathrm{cm})\end{array}$} & \multicolumn{2}{c}{ Dipterocarp } & \multicolumn{2}{c}{ Non Dipterocarp } & \multicolumn{2}{c}{ Non-commercial } \\
\cline { 2 - 6 } & $\begin{array}{c}\text { Volume } \\
\left(\mathrm{m}^{3} / \text { tree }\right)\end{array}$ & $\begin{array}{c}\text { Basal Area } \\
\left(\mathrm{m}^{2} / \text { tree }\right)\end{array}$ & $\begin{array}{c}\text { Volume } \\
\left(\mathrm{m}^{3} / \text { tree }\right)\end{array}$ & $\begin{array}{c}\text { Basal Area } \\
\left(\mathrm{m}^{2} / \text { tree }\right)\end{array}$ & $\begin{array}{c}\text { Volume } \\
\left(\mathrm{m}^{3} / \text { tree }\right)\end{array}$ & $\begin{array}{c}\text { Basal Area } \\
\left(\mathrm{m}^{2} / \text { tree }\right)\end{array}$ \\
\hline $10-14$ & 0.17 & 0.012 & 0.06 & 0.012 & 0.06 & 0.012 \\
$15-19$ & 0.25 & 0.024 & 0.13 & 0.024 & 0.13 & 0.024 \\
$20-24$ & 0.41 & 0.040 & 0.28 & 0.040 & 0.28 & 0.040 \\
$25-29$ & 0.64 & 0.059 & 0.49 & 0.059 & 0.49 & 0.059 \\
$30-34$ & 0.96 & 0.083 & 0.76 & 0.083 & 0.76 & 0.083 \\
$35-39$ & 1.35 & 0.110 & 1.11 & 0.110 & 1.11 & 0.110 \\
$40-44$ & 1.82 & 0.142 & 1.51 & 0.142 & 1.51 & 0.142 \\
$45-49$ & 2.37 & 0.177 & 1.99 & 0.177 & 1.99 & 0.177 \\
$50-54$ & 3.00 & 0.217 & 2.53 & 0.217 & 2.53 & 0.217 \\
$55-59$ & 3.70 & 0.260 & 3.13 & 0.260 & 3.13 & 0.260 \\
$60-64$ & 4.49 & 0.307 & 3.81 & 0.307 & 3.81 & 0.307 \\
$65-69$ & 5.35 & 0.358 & 4.54 & 0.358 & 4.54 & 0.358 \\
$\geq 70$ & 6.29 & 0.413 & 5.35 & 0.413 & 5.35 & 0.413 \\
\hline
\end{tabular}


Table A2.5. Value of trees in each species and diameter class

\begin{tabular}{|c|c|c|c|c|c|c|}
\hline \multirow{3}{*}{$\begin{array}{l}\text { Diameter } \\
(\mathrm{cm})\end{array}$} & \multicolumn{6}{|c|}{ Value of trees } \\
\hline & \multicolumn{2}{|c|}{ Dipterocarp } & \multicolumn{2}{|c|}{ Non Dipterocarp } & \multicolumn{2}{|c|}{ Non-commercial } \\
\hline & $\begin{array}{c}\mathrm{CL} \\
\text { (USD/tree) }\end{array}$ & $\begin{array}{c}\text { RIL } \\
\text { (USD/tree) }\end{array}$ & $\begin{array}{c}\mathrm{CL} \\
\text { (USD/tree) }\end{array}$ & $\begin{array}{c}\text { RIL } \\
\text { (USD/tree) }\end{array}$ & $\begin{array}{c}\mathrm{CL} \\
\text { (USD/tree) }\end{array}$ & $\begin{array}{c}\text { RIL } \\
\text { (USD/tree) }\end{array}$ \\
\hline $10-14$ & 0 & 0 & 0 & 0 & 0 & 0 \\
\hline $15-19$ & 0 & 0 & 0 & 0 & 0 & 0 \\
\hline $20-24$ & 0 & 0 & 0 & 0 & 0 & 0 \\
\hline $25-29$ & 0 & 0 & 0 & 0 & 0 & 0 \\
\hline $30-34$ & 0 & 0 & 0 & 0 & 0 & 0 \\
\hline $35-39$ & -1 & -1 & 0 & 0 & 0 & 0 \\
\hline $40-44$ & 87 & 89 & 39 & 41 & -1 & -1 \\
\hline $45-49$ & 113 & 116 & 51 & 54 & -1 & -1 \\
\hline $50-54$ & 143 & 147 & 65 & 68 & -1 & -1 \\
\hline $55-59$ & 176 & 181 & 81 & 85 & -1 & -1 \\
\hline $60-64$ & 214 & 219 & 98 & 103 & -2 & -2 \\
\hline $65-69$ & 255 & 262 & 117 & 123 & -2 & -2 \\
\hline$\geq 70$ & 299 & 308 & 137 & 144 & -2 & -2 \\
\hline
\end{tabular}

Table A2.6. Number of trees in steady state forest that maximizes LEV in CL and RIL with minimum diameter cutting limit $>40 \mathrm{~cm}$

\begin{tabular}{|c|c|c|c|c|c|c|c|c|c|c|c|c|c|c|c|c|c|c|}
\hline \multirow{3}{*}{$\begin{array}{l}\text { Dia- } \\
\text { meter } \\
(\mathrm{cm})\end{array}$} & \multicolumn{6}{|c|}{ Dipterocarp } & \multicolumn{6}{|c|}{ Non Dipterocarp } & \multicolumn{6}{|c|}{ Non Commercial } \\
\hline & \multicolumn{2}{|c|}{ Stock } & \multicolumn{2}{|c|}{ harvest } & \multicolumn{2}{|c|}{ Damage } & \multicolumn{2}{|c|}{ Stock } & \multicolumn{2}{|c|}{ harvest } & \multicolumn{2}{|c|}{ damage } & \multicolumn{2}{|c|}{ Stock } & \multicolumn{2}{|c|}{ harvest } & \multicolumn{2}{|c|}{ damage } \\
\hline & $\begin{array}{c}\text { CL } \\
40\end{array}$ & $\begin{array}{c}\text { RIL } \\
40\end{array}$ & $\begin{array}{c}\text { CL } \\
40\end{array}$ & $\begin{array}{c}\text { RIL } \\
40\end{array}$ & $\begin{array}{l}\text { CL } \\
40\end{array}$ & $\begin{array}{c}\text { RIL } \\
40\end{array}$ & $\begin{array}{c}\text { CL } \\
40\end{array}$ & $\begin{array}{c}\text { RIL } \\
40\end{array}$ & $\begin{array}{l}\text { CL } \\
40\end{array}$ & $\begin{array}{c}\text { RIL } \\
40\end{array}$ & $\begin{array}{c}\text { CL } \\
40\end{array}$ & $\begin{array}{c}\text { RIL } \\
40\end{array}$ & $\begin{array}{l}\text { CL } \\
40\end{array}$ & $\begin{array}{c}\text { RIL } \\
40\end{array}$ & $\begin{array}{c}\text { CL } \\
40\end{array}$ & $\begin{array}{c}\text { RIL } \\
40\end{array}$ & $\begin{array}{l}\text { CL } \\
40\end{array}$ & $\begin{array}{c}\text { RIL } \\
40\end{array}$ \\
\hline $10-14$ & 22 & 22 & 0 & 0 & 7 & 7 & 29 & 29 & 0 & 0 & 8 & 9 & 10 & 10 & 0 & 0 & 3 & 4 \\
\hline $15-19$ & 15 & 16 & 0 & 0 & 5 & 5 & 25 & 25 & 0 & 0 & 6 & 7 & 7 & 7 & 0 & 0 & 2 & 2 \\
\hline $20-24$ & 11 & 11 & 0 & 0 & 3 & 4 & 20 & 20 & 0 & 0 & 5 & 5 & 5 & 5 & 0 & 0 & 1 & 1 \\
\hline $25-29$ & 8 & 8 & 0 & 0 & 3 & 3 & 15 & 15 & 0 & 0 & 3 & 3 & 3 & 3 & 0 & 0 & 1 & 1 \\
\hline $30-34$ & 6 & 6 & 0 & 0 & 2 & 2 & 11 & 11 & 0 & 0 & 2 & 2 & 2 & 2 & 0 & 0 & 0 & 0 \\
\hline $35-39$ & 5 & 5 & 0 & 0 & 2 & 1 & 7 & 7 & 0 & 0 & 1 & 1 & 1 & 1 & 0 & 0 & 0 & 0 \\
\hline $40-44$ & 4 & 4 & 2 & 3 & 1 & 2 & 4 & 4 & 1 & 1 & 1 & 1 & 1 & 1 & 0 & 0 & 0 & 0 \\
\hline $45-49$ & 3 & 3 & 2 & 2 & 1 & 1 & 2 & 2 & 0 & 0 & 0 & 0 & 0 & 0 & 0 & 0 & 0 & 0 \\
\hline $50-54$ & 1 & 2 & 1 & 1 & 1 & 1 & 1 & 1 & 0 & 0 & 0 & 0 & 0 & 0 & 0 & 0 & 0 & 0 \\
\hline $55-59$ & 1 & 1 & 0 & 1 & 0 & 0 & 0 & 0 & 0 & 0 & 0 & 0 & 0 & 0 & 0 & 0 & 0 & 0 \\
\hline $60-64$ & 0 & 0 & 0 & 0 & 0 & 0 & 0 & 0 & 0 & 0 & 0 & 0 & 0 & 0 & 0 & 0 & 0 & 0 \\
\hline $65-69$ & 0 & 0 & 0 & 0 & 0 & 0 & 0 & 0 & 0 & 0 & 0 & 0 & 0 & 0 & 0 & 0 & 0 & 0 \\
\hline$\geq 70$ & 0 & 0 & 0 & 0 & 0 & 0 & 0 & 0 & 0 & 0 & 0 & 0 & 0 & 0 & 0 & 0 & 0 & 0 \\
\hline Total & 75 & 80 & 6 & 7 & 24 & 26 & 116 & 116 & 1 & 2 & 26 & 29 & 29 & 28 & 0 & 0 & 8 & 9 \\
\hline
\end{tabular}


Table A2.7. Number of trees in steady state forest that maximizes LEV in RIL with minimum diameter cutting limit $>50 \mathrm{~cm}$ and $60 \mathrm{~cm}$

\begin{tabular}{|c|c|c|c|c|c|c|c|c|c|c|c|c|c|c|c|c|c|c|}
\hline \multirow{3}{*}{$\begin{array}{c}\text { Diam } \\
\text { eter } \\
(\mathrm{cm})\end{array}$} & \multicolumn{6}{|c|}{ Dipterocarp } & \multicolumn{6}{|c|}{ Non Dipterocarp } & \multicolumn{6}{|c|}{ Non Commercial } \\
\hline & \multicolumn{2}{|c|}{ Stock } & \multicolumn{2}{|c|}{ harvest } & \multicolumn{2}{|c|}{ Damage } & \multicolumn{2}{|c|}{ Stock } & \multicolumn{2}{|c|}{ harvest } & \multicolumn{2}{|c|}{ damage } & \multicolumn{2}{|c|}{ Stock } & \multicolumn{2}{|c|}{ harvest } & \multicolumn{2}{|c|}{ damage } \\
\hline & $\begin{array}{c}\text { RIL } \\
50\end{array}$ & $\begin{array}{c}\text { RIL } \\
60\end{array}$ & $\begin{array}{c}\text { RIL } \\
50\end{array}$ & $\begin{array}{c}\text { RIL } \\
60\end{array}$ & $\begin{array}{c}\text { RIL } \\
50\end{array}$ & $\begin{array}{c}\text { RIL } \\
60\end{array}$ & $\begin{array}{c}\text { RIL } \\
50\end{array}$ & $\begin{array}{c}\text { RIL } \\
60\end{array}$ & $\begin{array}{c}\text { RIL } \\
50\end{array}$ & $\begin{array}{c}\text { RIL } \\
60\end{array}$ & $\begin{array}{c}\text { RIL } \\
50\end{array}$ & $\begin{array}{c}\text { RIL } \\
60\end{array}$ & $\begin{array}{c}\text { RIL } \\
50\end{array}$ & $\begin{array}{c}\text { RIL } \\
60\end{array}$ & $\begin{array}{c}\text { RIL } \\
50\end{array}$ & $\begin{array}{c}\text { RIL } \\
60\end{array}$ & $\begin{array}{c}\text { RIL } \\
50\end{array}$ & $\begin{array}{c}\text { RIL } \\
60\end{array}$ \\
\hline $10-14$ & 22 & 23 & 0 & 0 & 5 & 4 & 28 & 28 & 0 & 0 & 6 & 4 & 11 & 10 & 0 & 0 & 3 & 2 \\
\hline $15-19$ & 16 & 16 & 0 & 0 & 4 & 3 & 22 & 22 & 0 & 0 & 5 & 3 & 7 & 7 & 0 & 0 & 2 & 1 \\
\hline $20-24$ & 12 & 12 & 0 & 0 & 3 & 2 & 16 & 16 & 0 & 0 & 4 & 3 & 4 & 4 & 0 & 0 & 1 & 1 \\
\hline $25-29$ & 9 & 9 & 0 & 0 & 2 & 1 & 11 & 12 & 0 & 0 & 3 & 2 & 3 & 3 & 0 & 0 & 1 & 0 \\
\hline $30-34$ & 7 & 8 & 0 & 0 & 1 & 1 & 7 & 8 & 0 & 0 & 1 & 1 & 1 & 1 & 0 & 0 & 0 & 0 \\
\hline $35-39$ & 6 & 6 & 0 & 0 & 1 & 1 & 4 & 5 & 0 & 0 & 1 & 1 & 1 & 1 & 0 & 0 & 0 & 0 \\
\hline $40-44$ & 5 & 5 & 0 & 0 & 1 & 1 & 2 & 3 & 0 & 0 & 1 & 0 & 0 & 0 & 0 & 0 & 0 & 0 \\
\hline $45-49$ & 4 & 4 & 0 & 0 & 1 & 1 & 1 & 1 & 0 & 0 & 0 & 0 & 0 & 0 & 0 & 0 & 0 & 0 \\
\hline $50-54$ & 3 & 4 & 2 & 0 & 1 & 1 & 0 & 1 & 0 & 0 & 0 & 0 & 0 & 0 & 0 & 0 & 0 & 0 \\
\hline $55-59$ & 2 & 3 & 2 & 0 & 0 & 0 & 0 & 0 & 0 & 0 & 0 & 0 & 0 & 0 & 0 & 0 & 0 & 0 \\
\hline $60-64$ & 1 & 2 & 1 & 2 & 0 & 0 & 0 & 0 & 0 & 0 & 0 & 0 & 0 & 0 & 0 & 0 & 0 & 0 \\
\hline $65-69$ & 0 & 1 & 0 & 1 & 0 & 0 & 0 & 0 & 0 & 0 & 0 & 0 & 0 & 0 & 0 & 0 & 0 & 0 \\
\hline$\geq 70$ & 0 & 1 & 0 & 1 & 0 & 0 & 0 & 0 & 0 & 0 & 0 & 0 & 0 & 0 & 0 & 0 & 0 & 0 \\
\hline Total & 87 & 96 & 6 & 4 & 20 & 15 & 91 & 95 & 0 & 0 & 21 & 15 & 27 & 28 & 0 & 0 & 6 & 4 \\
\hline
\end{tabular}

Table A2.8. LEV of joint production of timber and avoiding emissions from forest degradation at discount rate of $2 \%$

\begin{tabular}{|c|c|c|c|c|c|c|c|}
\hline \multirow{2}{*}{\multicolumn{2}{|c|}{$\begin{array}{l}\text { Price temporary carbon credit }\left(\mathrm{USD} / \mathrm{tCO}_{2}\right) \\
\text { Price permanent carbon credit }\left(\mathrm{USD} / \mathrm{tCO}_{2}\right)\end{array}$}} & \multirow{2}{*}{$\begin{array}{l}0 \\
0\end{array}$} & \multirow{3}{*}{$\begin{array}{r}0.2 \\
2.7 \\
753\end{array}$} & \multirow{3}{*}{$\begin{array}{r}0.4 \\
5.3 \\
1025\end{array}$} & \multirow{3}{*}{$\begin{array}{r}1 \\
13.3 \\
3732\end{array}$} & \multirow{3}{*}{$\begin{array}{r}2 \\
26.5 \\
17666\end{array}$} & \multirow{3}{*}{$\begin{array}{r}3 \\
39.8 \\
32042\end{array}$} \\
\hline & & & & & & & \\
\hline $\mathrm{CL}$ & LEV (USD/ha) & 667 & & & & & \\
\hline & $\mathrm{T}^{*}($ year $)$ & 32 & 46 & 66 & 100 & 100 & 100 \\
\hline & Vol harvested (m3/ha) & 20 & 27 & 40 & 45 & 0 & 0 \\
\hline & $\mathrm{CO} 2$-eq (ton/ha) & 134 & 169 & 230 & 432 & 661 & 661 \\
\hline \multirow[t]{4}{*}{ RIL40 } & LEV (USD/ha) & 701 & 880 & 1234 & 4072 & 17651 & 32027 \\
\hline & $\mathrm{T}^{*}($ year $)$ & 38 & 56 & 70 & 100 & 100 & 100 \\
\hline & Vol harvested (m3/ha) & 26 & 37 & 47 & 48 & 0 & 0 \\
\hline & CO2-eq (ton/ha) & 155 & 194 & 246 & 452 & 661 & 661 \\
\hline \multirow[t]{4}{*}{ RIL50 } & LEV (USD/ha) & 244 & 659 & 1187 & 4072 & 17651 & 32027 \\
\hline & $\mathrm{T}^{*}($ year $)$ & 32 & 46 & 64 & 100 & 100 & 100 \\
\hline & Vol harvested (m3/ha) & 26 & 36 & 46 & 48 & 0 & 0 \\
\hline & CO2-eq (ton/ha) & 203 & 229 & 263 & 452 & 661 & 661 \\
\hline \multirow[t]{4}{*}{ RIL60 } & LEV (USD/ha) & -798 & -67 & 753 & 4072 & 17651 & 32027 \\
\hline & $\mathrm{T}^{*}($ year) & 26 & 34 & 50 & 100 & 100 & 100 \\
\hline & Vol harvested (m3/ha) & 24 & 30 & 40 & 48 & 0 & 0 \\
\hline & CO2-eq (ton/ha) & 261 & 280 & 309 & 452 & 661 & 661 \\
\hline
\end{tabular}


Table A2.9. LEV of joint production of timber and avoiding emissions from forest degradation at discount rate of $6 \%$

\begin{tabular}{|c|c|c|c|c|c|c|c|}
\hline \multirow{2}{*}{\multicolumn{2}{|c|}{$\begin{array}{l}\text { Price temporary carbon credit }\left(\mathrm{USD} / \mathrm{tCO}_{2}\right) \\
\text { Price permanent carbon credit }\left(\mathrm{USD} / \mathrm{tCO}_{2}\right)\end{array}$}} & \multirow{2}{*}{$\begin{array}{l}0 \\
0\end{array}$} & \multirow{2}{*}{$\begin{array}{l}0.2 \\
2.7\end{array}$} & \multirow{3}{*}{$\begin{array}{r}0.4 \\
5.3 \\
96\end{array}$} & \multirow{3}{*}{$\begin{array}{r}1 \\
13.3 \\
115\end{array}$} & \multirow{3}{*}{$\begin{array}{r}2 \\
26.5 \\
909\end{array}$} & \multirow{3}{*}{$\begin{array}{r}3 \\
39.8 \\
5228\end{array}$} \\
\hline & & & & & & & \\
\hline CL & LEV (USD/ha) & 140 & 115 & & & & \\
\hline & $\mathrm{T}^{*}($ year $)$ & 22 & 26 & 32 & 58 & 70 & 100 \\
\hline & Vol harvested (m3/ha) & 14 & 16 & 20 & 33 & 42 & 0 \\
\hline & $\mathrm{CO} 2$-eq (ton/ha) & 117 & 123 & 134 & 190 & 361 & 661 \\
\hline \multirow[t]{4}{*}{ RIL40 } & LEV (USD/ha) & 133 & 123 & 132 & 278 & 1181 & 5228 \\
\hline & $\mathrm{T}^{*}$ (year) & 26 & 32 & 50 & 74 & 82 & 100 \\
\hline & Vol harvested (m3/ha) & 18 & 22 & 33 & 46 & 51 & 0.0 \\
\hline & $\mathrm{CO} 2$-eq (ton/ha) & 132 & 143 & 177 & 227 & 380 & 661 \\
\hline \multirow[t]{4}{*}{ RIL50 } & LEV (USD/ha) & -532 & -431 & -316 & 134 & 1181 & 5228 \\
\hline & $\mathrm{T}^{*}($ year $)$ & 22 & 28 & 42 & 72 & 82 & 100 \\
\hline & Vol harvested (m3/ha) & 19 & 23 & 33 & 50 & 51 & 0 \\
\hline & $\mathrm{CO} 2$-eq (ton/ha) & 184 & 196 & 222 & 272 & 380 & 661 \\
\hline \multirow[t]{4}{*}{ RIL60 } & LEV (USD/ha) & -1654 & -1425 & -1188 & -368 & 1181 & 5228 \\
\hline & $\mathrm{T}^{*}($ year $)$ & 18 & 20 & 24 & 62 & 82 & 100 \\
\hline & Vol harvested (m3/ha) & 17 & 19 & 22 & 46 & 51 & 0 \\
\hline & $\mathrm{CO} 2$-eq (ton/ha) & 245 & 251 & 259 & 328 & 380 & 661 \\
\hline
\end{tabular}

